\title{
Modeling Potential Distribution and Carbon Dynamics of Natural Terrestrial Ecosystems: A Case Study of Turkey
}

\author{
Fatih Evrendilek ${ }^{1, *}$, Suha Berberoglu ${ }^{2}$, Onder Gulbeyaz ${ }^{1}$ and Can Ertekin ${ }^{3}$
}

1 Department of Environmental Engineering, Abant Izzet Baysal University, Golkoy Campus, 14280

Bolu, Turkey; Tel: +90 374253 4640, Fax: +90 3742534506

E-mail: fevrendilek@yahoo.com; fevrendilek@ibu.edu.tr

2 Department of Landscape Architecture, Faculty of Agriculture, Cukurova University, 01330 Adana, Turkey.

E-mail: suha@cu.edu.tr

3 Department of Agricultural Machinery, Faculty of Agriculture, Akdeniz University, Antalya, Turkey.

E-mail: ertekin@akdeniz.edu.tr

* Author to whom correspondence should be addressed.

Received: 4 October 2008 / Accepted: 11 October 2007 / Published: 11 October 2007

\begin{abstract}
We derived a simple model that relates the classification of biogeoclimate zones, (co)existence and fractional coverage of plant functional types (PFTs), and patterns of ecosystem carbon (C) stocks to long-term average values of biogeoclimatic indices in a time- and space-varying fashion from climate-vegetation equilibrium models. Proposed Dynamic Ecosystem Classification and Productivity (DECP) model is based on the spatial interpolation of annual biogeoclimatic variables through multiple linear regression (MLR) models and inverse distance weighting (IDW) and was applied to the entire Turkey of $780,595 \mathrm{~km}^{2}$ on a $500 \mathrm{~m}$ x $500 \mathrm{~m}$ grid resolution. Estimated total net primary production (TNPP) values of mutually exclusive PFTs ranged from $108 \pm 26$ to $891 \pm 207 \mathrm{Tg} \mathrm{C} \mathrm{yr}^{-1}$ under the optimal conditions and from $16 \pm 7$ to $58 \pm 23 \mathrm{Tg} \mathrm{C} \mathrm{yr}^{-1}$ under the growthlimiting conditions for all the natural ecosystems in Turkey. Total NPP values of coexisting PFTs ranged from $178 \pm 36$ to $1231 \pm 253 \mathrm{Tg} \mathrm{C} \mathrm{yr}^{-1}$ under the optimal conditions and from $23 \pm 8$ to $92 \pm 31 \mathrm{Tg} \mathrm{C} \mathrm{yr}^{-1}$ under the growth-limiting conditions. The national steady state soil organic carbon (SOC) storage in the surface one meter of soil was estimated to range from $7.5 \pm 1.8$ to $36.7 \pm 7.8 \mathrm{Pg} \mathrm{C} \mathrm{yr}^{-1}$ under the optimal conditions and

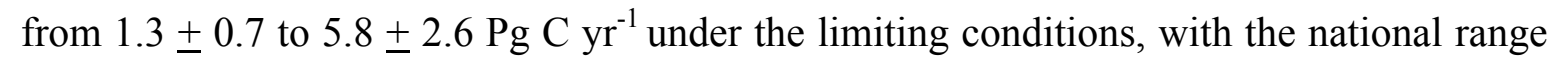


of 1.3 to $36.7 \mathrm{Pg} \mathrm{C}$ elucidating $0.1 \%$ and $2.8 \%$ of the global SOC value (1272.4 $\mathrm{Pg} \mathrm{C}$ ), respectively. Our comparisons with literature compilations indicate that estimated patterns of biogeoclimate zones, PFTs, TNPP and SOC storage by the DECP model agree reasonably well with measurements from field and remotely sensed data.

Keywords: Biogeoclimate zones; Land cover; Spatio-temporal modeling; Net primary productivity; Soil organic carbon; Turkey.

\section{Introduction}

Understanding biogeoclimatic controls and its spatio-temporal variability is essential to the quantification of the dynamics of biological productivity under a changing environment at the local, regional and global scales [1-5]. Our current understanding of the seasonal and geographical distribution of the global terrestrial net primary productivity (NPP) estimated at $56.4 \mathrm{Pg}$ carbon (C) $\mathrm{yr}^{-}$ ${ }^{1}$ (on average, $426 \mathrm{~g} \mathrm{C} \mathrm{m}^{-2} \mathrm{yr}^{-1}$ ) [6] and $59 \mathrm{Pg} \mathrm{C} \mathrm{yr}^{-1}$ is based on the extrapolation of local and regional studies to the global scale $\left(1 \mathrm{Pg}=10^{15} \mathrm{~g}\right)[7,8]$. Dynamic classification of regional plant functional types (PFTs) in response to changes in forcing biogeoclimate variables such as elevation, geographical position, moisture index, biotemperature, and growing season precipitation is needed for a better estimation of the global NPP, sustainable management of natural resources, and modelling of biogeochemical cycles [9-11,55]. Changes in the predominant PFTs are primarily determined using the analysis of time series datasets derived from one or the combination of the following sources: (1) atlases [12], (2) remote sensing [13], and (3) biogeoclimate relationships [14-16]. The use of atlases and satellite images serves to describe the actual distribution of natural and cultivated vegetation patterns, while (geo)statistical and process-based models based on biogeoclimatic controls serve not only to describe but also to predict the potential distribution of natural PFTs and changes in patterns of plant and soil $\mathrm{C}$ storage in a changing global climate.

Flux rates, storage sizes, and residence times of $\mathrm{C}$ cycle are intimately coupled with the distribution patterns of biogeoclimate zones. A various number of spatial interpolation techniques, multiple regression models, biogeoclimate indices, and land-cover classification systems have been implemented to quantify dynamics of terrestrial biogeochemical metabolism including NPP and net ecosystem productivity (NEP) [14,15,17-19]. Due to the impracticality of continuous field NPP measurements of all ecosystem types at the regional and global scales by harvest or ${ }^{14} \mathrm{C}$-based methods, various algorithms have been devised to spatially interpolate biogeoclimatic datasets for each pixel of a gridded digital elevation model (DEM) [20] and to use them as inputs into processed-based ecosystem models [21-27].

In this study, we present a simple algorithm of Dynamic Ecosystem Classification and Productivity (called DECP hereafter) to quantify the dynamics of potential natural PFTs, NPP, and soil organic carbon (SOC) as a function of biogeoclimatic determinants that reflect the geo-referenced long-term mean bioclimate and apply it to the entire Turkey of $780,595 \mathrm{~km}^{2}$. 


\section{Materials and Methods}

\subsection{Description of Study Region}

Turkey $\left(36-42^{\circ} \mathrm{N}\right.$ and $\left.26-45^{\circ} \mathrm{E}\right)$ is located where Asia, Europe, and the Middle East meet, with an average altitude of $1250 \mathrm{~m}$. The temperature reaches $45^{\circ} \mathrm{C}$ in July in the southeastern region, and falls to $-30{ }^{\circ} \mathrm{C}$ in February in the eastern regions, with a mean annual temperature of around $13{ }^{\circ} \mathrm{C}$. Annual precipitation ranges from $258 \mathrm{~mm}$ in the central and southeastern regions to $2220 \mathrm{~mm}$ in the northeastern Black Sea coasts, with a mean annual precipitation of around $634 \mathrm{~mm}$. Annual evapotranspiration varies from $624 \mathrm{~mm}$ in the eastern region to $2400 \mathrm{~mm}$ in the southeastern region, with a mean annual evapotranspiration of $1280 \mathrm{~mm}$ according to the long-term mean climate data between 1968 and 2004 [32].

Parent materials range from sedimentary rocks of highly calcareous clays, limestone, and dolomites; igneous rocks of basalt; and granite to metamorphic rocks of schists, serpentine, and marble [28]. The geological structure consists mostly of unconsolidated deposits $(23 \%$ of the total area of Turkey) igneous rocks (18\%), metamorphic and igneous rocks (13\%), sedimentary rocks (12\%), metamorphic rocks (8\%), and consolidated-clastic-sedimentary rocks (5\%) [29]. The prevalence of steep slopes with rapid erosion results in mostly shallow, weathering limited soils (Inceptisols and Entisols) except on footslopes and lowlands. Inceptisol-alfisol regions comprise about $26 \%$ of the total area of Turkey, inceptisols $22 \%$, alfisol-vertisol regions $14 \%$, inceptisol-salic great group-vertisol regions $8.4 \%$, entisol-inceptisol-salic great group-alfisol regions $6 \%$, and inceptisol-vertisol-alfisol regions $4 \%$, and inceptisol-spodosols $0.3 \%$ [29-31]. The alluvial soils ( $8 \%$ ) occupy the deltas, coastal strips, stream valleys, and flood plains. Mollisols occur mainly over calcareous parent materials in the central Anatolia region, over basalt parent materials in the southeastern Anatolia region, and in valleys and on footslopes in the Aegean region [30].

\subsection{Derivation of Bioclimatic Indices}

Monthly climate data in Turkey were obtained from 269 meteorological stations for the period of 1968 to 2004 and included solar radiation (SR, MJ m ${ }^{-2}$ ), mean, minimum and maximum air temperature $\left(\mathrm{T}_{\text {mean }}, \mathrm{T}_{\min }\right.$ and $\left.\mathrm{T}_{\max },{ }^{\circ} \mathrm{C}\right)$, cloudiness (CLD, \%), potential evapotranspiration (PET, mm), precipitation (PPT, $\mathrm{mm}$ ), and soil temperature (0 to $10 \mathrm{~cm}$ in depth) $\left(\mathrm{ST}_{10},{ }^{\circ} \mathrm{C}\right)$ [32]. The three Holdridge life zone (HLZ) classification indices of biotemperature (BT), potential evapotranspiration ratio (PER), and potential evapotranspiration $\left(\mathrm{PET}_{\mathrm{HLZ}}\right)$ [15], and the following three bioclimatic indices used by Box [18] were derived from the climate data for each data point as follows:

$$
\mathrm{PER}=\frac{\mathrm{PET}_{\mathrm{HLZ}}}{\mathrm{PPT}}=\frac{58.93 \mathrm{BT}}{\mathrm{PPT}}
$$

where mean annual biotemperature $\left(\mathrm{BT},{ }^{\circ} \mathrm{C}\right)$ was calculated by substituting monthly mean temperatures $\left(\mathrm{MMT}_{\mathrm{i}}\right)$ both above $30{ }^{\circ} \mathrm{C}$ and below $0{ }^{\circ} \mathrm{C}$ with $0{ }^{\circ} \mathrm{C}[15]$. 


$$
\mathrm{MMT}_{\text {coldest }}=\frac{1}{3} \sum_{i=1}^{3} \mathrm{MMT}_{\min i}
$$

where $\mathrm{MMT}_{\text {coldest }}$ is mean monthly temperature of the three coldest months $\left(\mathrm{MMT}_{\min },{ }^{\circ} \mathrm{C}\right)$.

$$
\mathrm{GSP}=\frac{1}{3} \sum_{i=1}^{3} \mathrm{MMP}_{\text {warmest } i}
$$

where GSP is growing season precipitation calculated as the mean monthly precipitation $(\mathrm{mm})$ of the three warmest months $\left(\mathrm{MMP}_{\text {warmesti)}}\right.$.

$$
\mathrm{MI}=\frac{\mathrm{PPT}}{\mathrm{PET}_{\mathrm{HLZ}}}
$$

where annual moisture index (MI) refers to the ratio of the mean annual precipitation (PPT, $\mathrm{mm} \mathrm{yr}^{-1}$ )

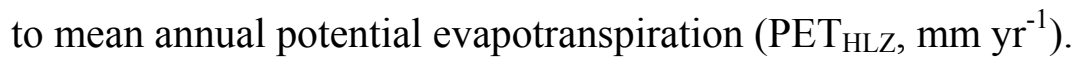

\subsection{Mapping Biogeoclimate Zones and Potential Natural Plant Functional Types}

A national map of potential natural vegetation was derived from (biogeo)climatic variables and indices, assuming a natural vegetation distribution is in equilibrium with the mean long-term climate, without human interference and cultivated vegetation types. Natural vegetation is thus separated into three broad PFTs: trees, shrubs, and grass. Three life-forms (evergreen needleleaf, EN; deciduous broadleaf, DB; and evergreen broadleaf, EB) were distinguished for tree and shrub covers in terms of leaf phenology (evergreen vs. deciduous) and leaf shape (needleleaf vs. broadleaf), and one grass lifeform (C3) in terms of photosynthetic pathway since the life-forms of deciduous needleleaf, and C4 grass species are not found in the prevailing natural vegetation of Turkey.

The fractional cover of trees $\left(f_{T}\right)$ was estimated from the annual MI and assumed to linearly decrease from $100 \%$ at $\mathrm{MI}=1.0$ to $0 \%$ at $\mathrm{MI}=0.6$ as follows [18]:

$$
f_{\mathrm{T}}= \begin{cases}0 & \text { for } \mathrm{MI}<0.6 \\ (\mathrm{MI}-0.6) / 0.4 & \text { for } 0.6 \leq \mathrm{MI} \leq 1.0 \\ 1 & \text { for } \mathrm{MI}>1.0\end{cases}
$$

Treeline at altitudes beyond which tree cover fraction becomes zero was assumed to occur at a growing degree-day sum $\left(\mathrm{GDD}_{5}\right) \leq 350$ according to Woodward [33]. $\mathrm{GDD}_{5}$ was calculated thus:

$$
\mathrm{GDD}_{5}=\sum_{i=1}^{12}\left(\left(\frac{M M T_{\max i}+M M T_{\min i}}{2}\right)-T_{\mathrm{b}}\right) \mathrm{m}_{i}
$$


where $\mathrm{GDD}_{5}$ refers to the annual sum of monthly mean temperatures above the base temperature $\left(T_{\mathrm{b}}=\right.$ $\left.5{ }^{\circ} \mathrm{C}\right)$ multiplied by the number of days in the $\operatorname{month}_{i}\left(\mathrm{~m}_{i}\right)$.

According to the 17-class land cover classification system of the International Geosphere-Biosphere Programme (IGBP) and the IGBP DISCover definition of forest (greater than $60 \%$ canopy cover), four tree cover classes of $<10 \%, 10-30 \%, 30-60 \%$ and $60-100 \%$ were assumed to translate to barren or sparsely vegetated, grassland (steppe), woodland/shrubland (W/S) and forest cover types, respectively [34]. Unlike the mutually exclusive four cover categories derived from the IGBP system, fractional shrub and grass covers compatible with the fractional forest cover were also mapped directly based on the assumption that the $500 \mathrm{~m} \times 500 \mathrm{~m}$ pixels do not all consist of a single PFT. The cover fractions of shrubs and C3 grass were estimated based on MLR models developed by Paruelo and Lauenroth [35] as follows:

$$
\begin{gathered}
f_{\mathrm{S}}=1.7105+1.5451 \mathrm{PPT}_{\mathrm{DJF}}-0.2918 \ln \mathrm{PPT}\left(n=70 ; R_{\text {adj. }}^{2}=0.62 ; P<0.001\right) \\
f_{\mathrm{C} 3}=1.1905-0.02909 \mathrm{MAT}+0.1781 \ln \mathrm{PPT}_{\mathrm{DJF}}-0.2383 \mathrm{BIOME}\left(n=69 ; R_{\text {adj. }}^{2}=0.37 ; P<0.001\right)
\end{gathered}
$$

where $f_{\mathrm{S}}$ and $f_{\mathrm{C} 3}$ refer to the cover fractions of shrubs and $\mathrm{C} 3$ grass, respectively, and were linearly normalized based on $1-f_{\mathrm{T}}$. $\mathrm{PPT}_{\mathrm{DJF}}$ is the ratio of PPT during the three winter months (December to February) to annual PPT. The value of BIOME is an indicator (dummy) variable representing grassland (1) vs. shrubland (2) and 1 at $f_{\mathrm{S}} \leq 0.2$ and 2 at $f_{\mathrm{S}}>0.2$.

Assignment of $f_{\mathrm{T}}$ to one of PFTs (evergreen needleleaf, EN; deciduous broadleaf, DB; evergreen broadleaf, EB) was based on $\mathrm{MMT}_{\text {coldest }}$ and GSP according to Box [18]. The mixture (100 to 0\%) of the PFTs $\left(f_{\mathrm{PFTs}}\right)$ was linearly interpolated according to Box [18] as follows:

$$
f \mathrm{PTFs}=\left\{\begin{array}{l}
100(0) \% \mathrm{EN} \text { to } 0(100) \% \mathrm{DB} \text { if }-15 \leq \mathrm{MMT}_{\text {coldest }} \leq 1.5 \text { at } \mathrm{GSP}>30 \mathrm{~mm} \\
100(0) \% \mathrm{DB} \text { to } 0(100) \% \mathrm{~EB} \text { if } 1.5 \leq \mathrm{MMT}_{\text {coldest }} \leq 18 \text { at } \mathrm{GSP}>30 \mathrm{~mm} \\
100(0) \% \mathrm{EN} \text { to } 0(100) \% \mathrm{~EB} \text { if }-15 \leq \mathrm{MMT}_{\text {coldest }} \leq 18 \text { at } \mathrm{GSP} \leq 30 \mathrm{~mm}
\end{array}\right.
$$

The (bio)climatic variables of $\mathrm{BT}, \mathrm{MMT}_{\text {coldest }}$, and GSP for the classification of biogeoclimate zones; MAT, PPT, $\mathrm{PET}_{\mathrm{HLZ}}, \mathrm{PPT}_{\mathrm{DJF}}, \mathrm{GDD}_{5}$, and soil temperature at the depth of 0 to $10 \mathrm{~cm}$ during the three warmest months (June to August) of growing season $\left(\mathrm{ST}_{\mathrm{JJA} 10}\right)$ for the cover fraction of PFTs; and $\mathrm{MMT}_{\text {coldest }}$ for the relative dominance of the life-form composition were mapped using geostatistical interpolation based on inverse distance weighted (IDW) method and multiple linear regression (MLR) models in ArcGIS 9.1 [36]. The spatial interpolation of the long-term mean annual bioclimatic variables was carried out for each (about $500 \mathrm{~m}$ x $500 \mathrm{~m}$ ) of 3,182,206 grid cells $\left(c a .780,595 \mathrm{~km}^{2}\right.$ ). IDW was used to create accurate surface maps of PPT and GSP, while the remaining bioclimatic variables were mapped based on their best MLR models using digital layers for each explanatory variable of DEM (m), latitude (LAT, m), longitude (LON, m), distance to sea (DtS, m), and aspect (Asp, compass degree) (Figure 1). Best MLR models were selected based on lowest $C \mathrm{p}$ and highest

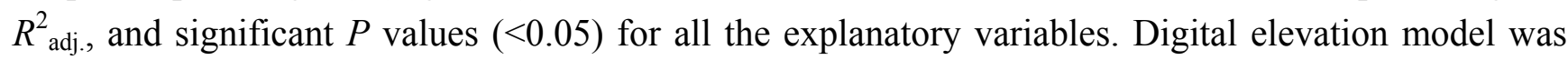
constructed from a 1:250,000 scale topographic map of Turkey generated by the Turkish General Command of Mapping, projected to the Universal Transverse Mercator (UTM) coordinates of the 
World Geographic System (WGS 1984) and re-sampled to a grid size of $500 \mathrm{~m}$. Digital maps of distance to sea $(\mathrm{m})$ and aspect $\left({ }^{\circ}\right)$ were derived from DEM using ArcGIS 9.1. The classification and distribution patterns of major biogeoclimate zones and PFTs were revealed overlaying the maps of the biogeoclimate variables, and detailed classification algorithm is presented in Figure 1.

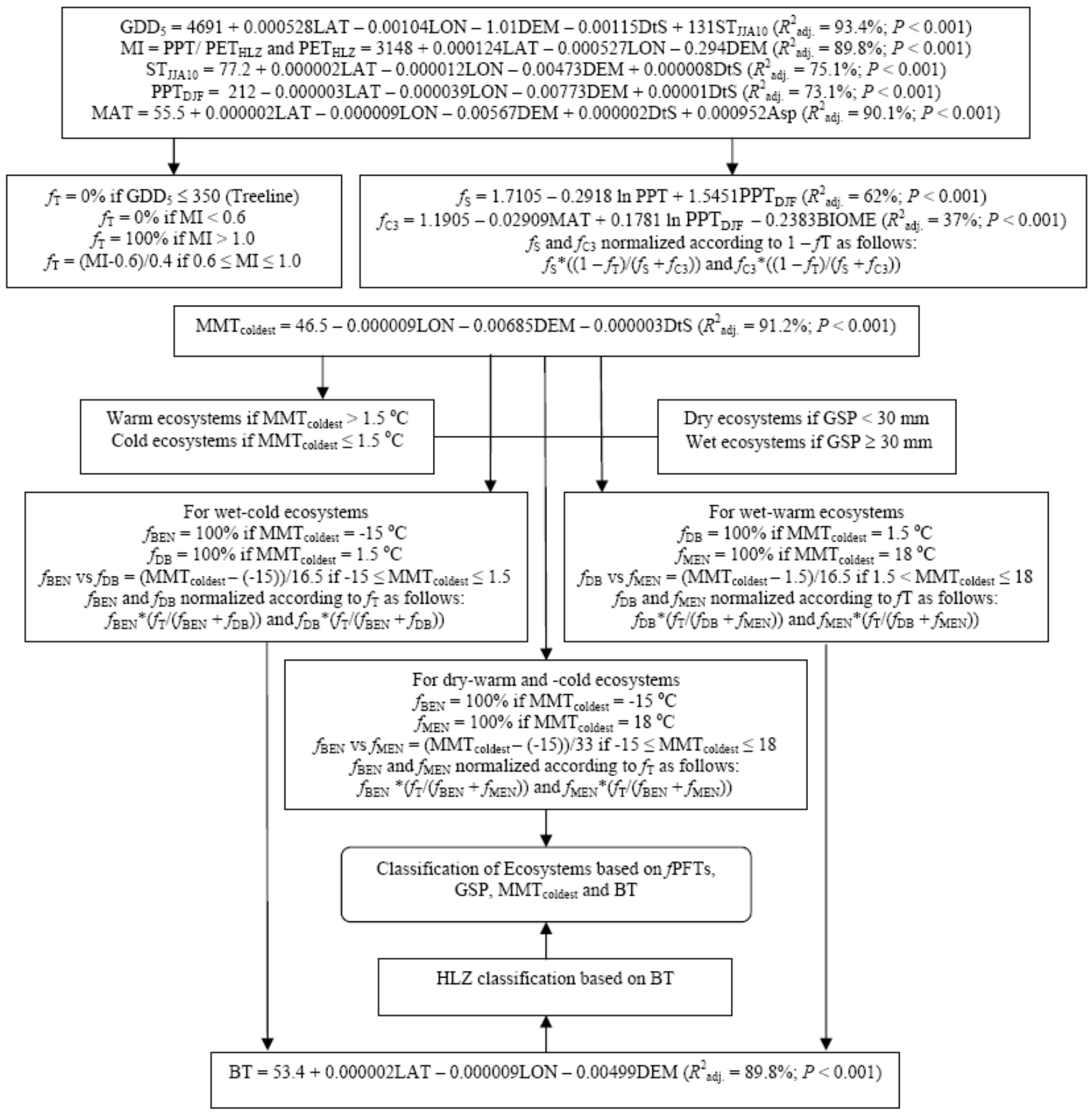

Figure 1. Biogeoclimatic classification algorithm of potential natural land cover and plant functional types (PFTs) in Turkey. 


\subsection{Quantifying Total Net Primary Productivity and Soil Organic Carbon Density}

The annual quantification of TNPP was based on the approach of light use efficiency (LUE) by Monteith [37,38], and Kumar and Monteith [39] as follows:

$$
\mathrm{TNPP}=0.45 \times \mathrm{LUE}_{\mathrm{T}} \times \mathrm{PAR} \times \text { fPFTs } \mathrm{x} \text { GSL } \mathrm{x} \text { LCF }
$$

where TNPP is total net primary productivity $\left(\mathrm{g} \mathrm{C} \mathrm{m}^{-2} \mathrm{yr}^{-1}\right)$. LUE $\mathrm{T}\left(\mathrm{g} \mathrm{DM} \mathrm{MJ}^{-1}\right)$ is light use efficiency of intercepted photosynthetically active radiation (PAR) into total dry matter (DM) of aboveground and belowground biomass. The value of 0.45 is a conversion coefficient for $\mathrm{C}$ content per unit DM biomass [40]. Biome-specific minimum, mean and maximum $L_{U E}$ values were obtained from Ruimy et al. [40] (Table 1). The fraction of incident PAR in incoming solar radiation was assumed to be 0.48 according to McCree [41]. The amount of intercepted PAR (IPAR) was assumed to be a function of fractional canopy covers of PFTs (fPFTs). The length of growing season period (GSL) (in days) was estimated as the number of days between the first and last months when the monthly minimum temperature $\left(\mathrm{T}_{\min }\right)<0{ }^{\circ} \mathrm{C}$. LCF refers to growth-limiting climate factors and is a reduction factor consisting of cloudiness (CLD) and humidity (MI) indices combined and normalized to a scale of 0 to 1 (LCF is 0 for completely growth-limiting conditions and 1 for optimal conditions). Aboveground $\mathrm{NPP}\left(\mathrm{NPP}_{\mathrm{A}}\right)$ and belowground NPP $\left(\mathrm{NPP}_{\mathrm{B}}\right)$ values were estimated based on the ratios of $\mathrm{NPP}_{\mathrm{B}}$ to $\mathrm{NPP}_{\mathrm{A}}$ compiled by the literature review of Ruimy et al. [40] (Table 1).

Table 1. Ranges of light use efficiency and ratios of belowground to aboveground net primary productivity (NPP) used for different plant functional types (PFTs) and biogeoclimate zones in the DECP model as modified from [40].

\begin{tabular}{|c|c|c|c|c|}
\hline \multirow[t]{2}{*}{ PFT } & \multirow[t]{2}{*}{$\begin{array}{c}\mathrm{NPP}_{\mathrm{B}}: \mathrm{NPP}_{\mathrm{A}} \\
\text { ratio }\end{array}$} & \multicolumn{3}{|c|}{$\begin{array}{c}\mathrm{LUE}_{\mathrm{T}} \\
\left(\mathrm{g} \mathrm{DM} \mathrm{MJ}^{-1}\right)\end{array}$} \\
\hline & & $\min$ & mean & $\max$ \\
\hline B ENF & $0.29-0.44$ & 0.73 & 1.57 & 1.69 \\
\hline CT ENF & $0.29-0.44$ & 0.73 & 1.57 & 1.69 \\
\hline WT DBF & $0.29-0.37$ & 0.31 & 1.01 & 2.72 \\
\hline M ENF & $0.17-0.25$ & 0.24 & 0.37 & 1.71 \\
\hline CT ENW/S & $0.29-0.44$ & 0.73 & 1.57 & 1.69 \\
\hline WT DBW/S & $0.29-0.37$ & 0.31 & 1.01 & 2.72 \\
\hline M ENW/S & $0.17-0.25$ & 0.24 & 0.37 & 1.71 \\
\hline CT steppe & $0.24-0.50$ & 0.6 & 1.26 & 2.71 \\
\hline WT steppe & $0.24-0.50$ & 0.6 & 1.26 & 2.71 \\
\hline M steppe & $0.24-0.50$ & 0.6 & 1.26 & 2.71 \\
\hline
\end{tabular}

$\mathrm{LUE}_{\mathrm{T}}$ : light use efficiency of intercepted photosynthetically active radiation (IPAR) into total dry matter (DM), NPP belowground net primary productivity, $\mathrm{NPP}_{\mathrm{A}}$ : aboveground net primary productivity, $\mathrm{B}$ : Boreal, CT: Cool Temperate, WT: Warm Temperate, M: Mediterranean, ENF: evergreen needleleaf forest, DBF: deciduous broadleaf forest, ENW/S: evergreen needleleaf woodland/shrubland, DBW/S: deciduous broadleaf woodland/shrubland. 
Net ecosystem productivity (NEP) can be quantified as follows:

$$
\mathrm{NEP}=\mathrm{TNPP}-R_{\mathrm{h}}
$$

where NEP represents the net ecosystem exchange of $\mathrm{CO}_{2}$ between the atmosphere and an ecosystem after accounting for the rate of $\mathrm{C}$ release from the soil to the atmosphere by respiration of microorganisms and roots $\left(R_{\mathrm{h}}\right)$. NEP reveals whether a terrestrial ecosystem is acting as a sink (net ecosystem sequestration) or a source (net ecosystem emission) for atmospheric $\mathrm{CO}_{2}$.

Based on the empirical Miami model modified by Friedlingstein et al. [42], originally developed by Lieth [43], TNPP values were also estimated as a function of PPT as follows:

$$
\mathrm{TNPP}_{(\mathrm{PPT})}=1.35\left(1-\mathrm{e}^{(-0.000664 \mathrm{PPT})}\right) \text { in nontropical regions }
$$


precipitation (PPT) $\left(\mathrm{mm} \mathrm{yr}^{-1}\right)$. Dai and Fung [44] reported that the modified Miami model estimated TNPP ranges of major terrestrial ecosystems closer to observations than the original Miami model.

The dynamics of SOC pools can be expressed in a single compartment by the following simple form of the first-order ordinary differential equation [45]:

$$
\frac{\mathrm{d} S O C}{\mathrm{~d} t}=A-k \times \mathrm{SOC}
$$

where SOC is the quantity of soil organic carbon aggregated as one compartment, $A$ the total mean annual litter (organic carbon) input to the soil, and $k$ the annual decomposition rate of SOC. At steady state, annual NPP should equal annual $R_{\mathrm{h}}$ which can be expressed as follows:

$$
R_{\mathrm{h}}=k \times \mathrm{SOC}=\mathrm{TNPP}
$$

Based on natural vegetation and undisturbed sites of the global observed SOC density dataset (100 $\mathrm{cm}$ in depth) [46], Yang et al. [47] reported a simple model for steady state $k$ values as follows:

$$
\begin{gathered}
k_{\mathrm{w}}=0.061 \mathrm{PER}^{0.7521}, \text { if PER }<1.0\left(R^{2}=0.153 ; n=683 ; P<0.001\right) \\
k_{\mathrm{d}}=0.0476 \mathrm{PER}^{-0.3305}, \text { if PER }>1.0\left(R^{2}=0.038 ; n=292 ; P<0.05\right)
\end{gathered}
$$

where MAT is mean annual temperature, $k_{\mathrm{w}}$ and $k_{\mathrm{d}}$ decomposition rates for wet and dry soil conditions, respectively. PER provides an aridity index that represents the interactive impact of BT and PPT on decomposition rates $[15,48,54]$. Soil organic carbon density $\left(\mathrm{kg} \mathrm{C} \mathrm{m}^{-3}\right)$ at steady state was directly derived from Eqn (14), based on the DECP model, the modified Miami model, and steady state $k$ values. As with the classification of biogeoclimate zones and PFTs, all the variables and parameters were mapped to a regular $500 \mathrm{~m}$ x $500 \mathrm{~m}$ pixel for the quantification of TNPP and SOC, based on their best MLRs and IDW interpolations, using ArcGIS 9.1. 


\section{Results}

\subsection{Biogeoclimate Zones}

Classification of biogeoclimate zones was based on the overlay of annual surface maps created by geographical position (latitude, longitude, elevation, and distance to sea)-sensitive MLR models of $\mathrm{MMT}_{\text {coldest }}$ and BT, and by the IDW interpolation of GSP. Best MLR models elucidated $89.8 \%$ of variation in BT as a function of LAT, LON, and DEM $\left(R_{\text {adj. }}^{2}=89.8 \% ; P<0.001 ; n=265\right)$ and $91.2 \%$ of variation in $\mathrm{MMT}_{\text {coldest }}$ as a function of LON, DEM, and DtS $\left(R_{\text {adj. }}^{2}=91.2 \% ; P<0.001 ; n=265\right)$ (Figure 1). The power that determines how influential neighboring points are to the point whose value is being interpolated (the higher the power, the lesser the influence from distant points) was used as the default optimized power value of 1.6274 in the IDW interpolation of GSP $(n=269)$. Cross-validation between predicted and observed values of GSP as a consequence of the IDW interpolation resulted in $R^{2}$ of $78.9 \%$, mean prediction error of $-0.0721 \mathrm{~mm}$, and root mean square prediction error of $9.58 \mathrm{~mm}$. The classification algorithm resulted in a total of 14 biogeoclimate zones $(P<0.001)$ (Figure 2). The resulting biogeoclimate zones were distinguished due to what appeared to be completely distinct or disjunct bioclimatic and geographical ranges. About $82 \%$ and $18 \%$ of Turkey appeared to comprise dry and moist ecosystems, respectively. (Sub)nival, alpine, boreal, cool temperate, warm temperate and Mediterranean ecosystems covered $0.19 \%, 0.64 \%, 5.54 \%, 51.72 \%, 33.89$, and $8.03 \%$ of Turkey, respectively (Table 2 ).

Table 2. Properties (mean \pm SD) and spatial extent of biogeoclimate zones along aridity and biotemperature gradients across Turkey.

\begin{tabular}{|c|c|c|c|c|c|c|c|}
\hline $\begin{array}{l}\text { Biogeoclimate } \\
\text { zone }\end{array}$ & $\begin{array}{c}\text { Mean } \\
\text { elevation } \\
(\mathrm{m})\end{array}$ & $\begin{array}{l}\text { Total } \\
\text { area } \\
\left(\mathrm{km}^{2}\right) \\
\end{array}$ & $\begin{array}{l}\text { GSP (mm } \\
\left.\text { month }^{-1}\right)\end{array}$ & $\begin{array}{l}\text { BT } \\
\left({ }^{\circ} \mathrm{C}\right)\end{array}$ & PER & $\begin{array}{l}\text { Dryness / } \\
\text { coldness }\end{array}$ & $\begin{array}{l}\text { Area } \\
\left(\mathrm{km}^{2}\right)\end{array}$ \\
\hline (Sub)nival & $3104 \pm 258$ & 1447 & $60 \pm 31$ & $0.6 \pm 0.9$ & $0.27 \pm 0.14$ & $\begin{array}{l}\text { Dry cold } \\
\text { Moist cold }\end{array}$ & $\begin{array}{l}664 \\
783\end{array}$ \\
\hline Alpine & $2831 \pm 220$ & 4997 & $42 \pm 28$ & $2.3 \pm 0.4$ & $0.33 \pm 0.10$ & $\begin{array}{l}\text { Dry cold } \\
\text { Moist cold }\end{array}$ & $\begin{array}{l}2073 \\
2924\end{array}$ \\
\hline Boreal & $2391 \pm 264$ & 43246 & $32 \pm 20$ & $4.8 \pm 0.8$ & $0.52 \pm 0.14$ & $\begin{array}{l}\text { Dry cold } \\
\text { Moist cold }\end{array}$ & $\begin{array}{l}24658 \\
18588\end{array}$ \\
\hline Cool Temperate & $1423 \pm 413$ & 403664 & $22 \pm 14$ & $9.6 \pm 1.5$ & $1.11 \pm 0.35$ & $\begin{array}{l}\text { Dry cold } \\
\text { Moist warm } \\
\text { Moist cold }\end{array}$ & $\begin{array}{r}328840 \\
10662 \\
64162\end{array}$ \\
\hline Warm Temperate & $663 \pm 371$ & 264563 & $19 \pm 17$ & $13.5 \pm 1.1$ & $1.40 \pm 0.41$ & $\begin{array}{l}\text { Dry warm } \\
\text { Moist warm } \\
\text { Moist cold }\end{array}$ & $\begin{array}{r}222015 \\
42239 \\
309\end{array}$ \\
\hline Mediterranean & $303 \pm 211$ & 62679 & $10 \pm 7$ & $17.3 \pm 1.0$ & $1.59 \pm 0.45$ & $\begin{array}{l}\text { Dry warm } \\
\text { Moist warm }\end{array}$ & $\begin{array}{r}61625 \\
1054\end{array}$ \\
\hline Total & $1141 \pm 655$ & 780595 & $21 \pm 16$ & $11.3 \pm 3.3$ & $1.21 \pm 0.44$ & & 100 \\
\hline
\end{tabular}

GSP: growing season precipitation, BT: biotemperature, PER: ratio of potential evapotranspiration to precipitation, SD: standard deviation 


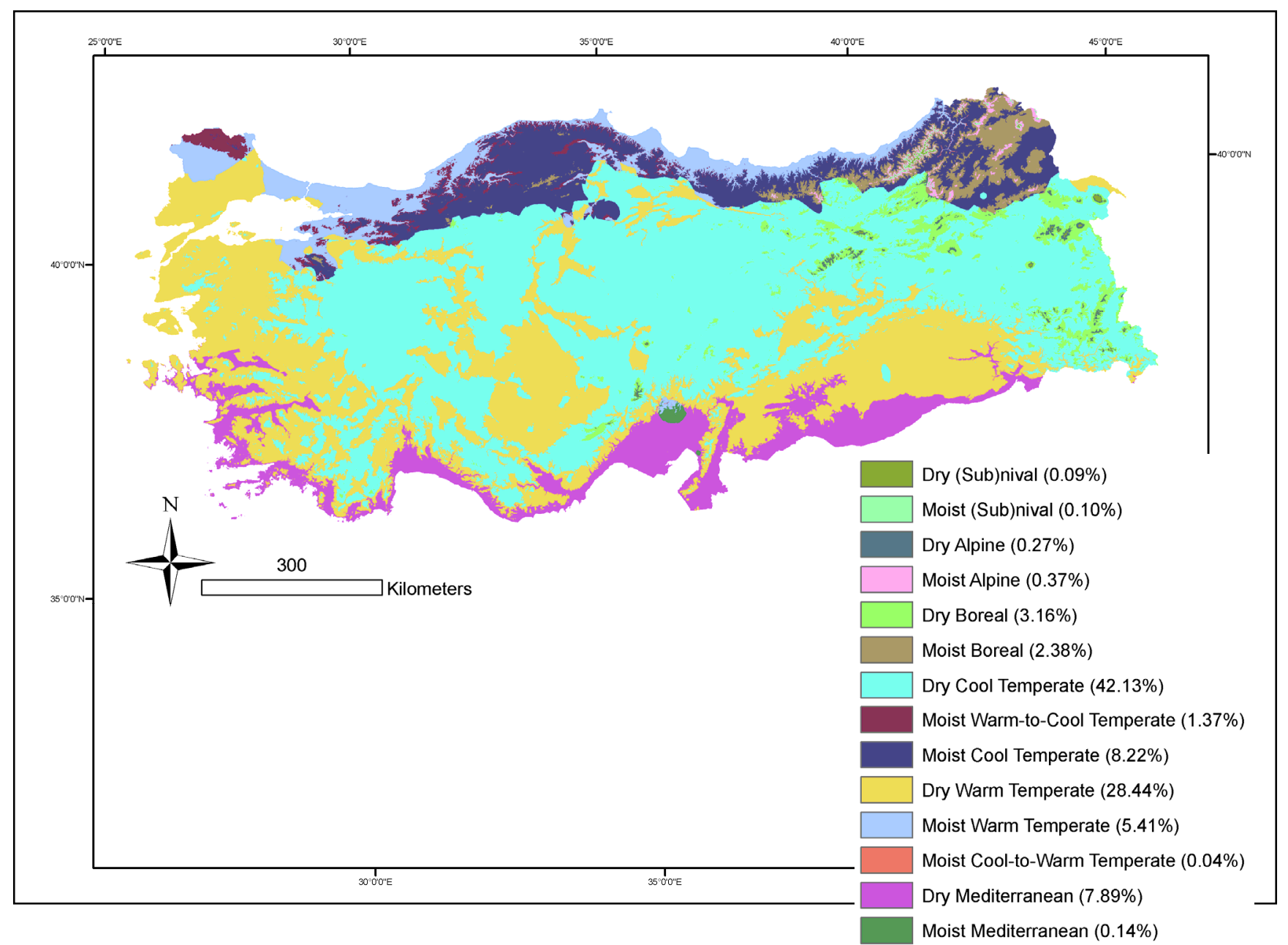

Figure 2. Spatial distribution and extent (\% of total area) of major biogeoclimatic zones in Turkey.

\subsection{Potential Natural Land Cover and Plant Functional Types}

The existence and fraction of tree cover drive potential distribution of natural land cover types and were derived from the MLR-based surface maps of $\mathrm{GDD}_{5}$, and MI (the ratio of PPT to PET $\mathrm{HLZ}_{\text {) }}$ (Figure 3). Best MLR models accounted for $93.4 \%$ of variation in $\mathrm{GDD}_{5}$ as a function of LAT, LON, DEM, DtS, and $\mathrm{ST}_{\text {JJA10 }}\left(R_{\text {adj. }}^{2}=93.4 \% ; P<0.001 ; n=265\right)$. The area above the treeline where $\mathrm{GDD}_{5}$ $\leq 350$ occupied $8096 \mathrm{~km}^{2}(1 \%)$ of Turkey, with the lowest treeline elevation occurring at $2275 \mathrm{~m}$ in the northwestern Turkey. The treeline elevation rose to $2900 \mathrm{~m}$ in the eastern Mediterranean region and declined to $2500 \mathrm{~m}$ in the eastern Turkey. The IDW interpolation of PPT, and MLR coefficients of PET $_{\mathrm{HLZ}}$ with digital layers of explanatory variables of LAT, LON, and DEM were used to create the final surface map of MI. Best MLR model explained $89.8 \%$ of variation in $\operatorname{PET}_{\mathrm{HLZ}}\left(R_{\text {adj. }}^{2}=89.8 \% ; P<\right.$ $0.001 ; n=265)$. An accurate surface map was generated from data points of long-term mean annual PPT based on the IDW interpolation with the optimized power value of 1.3272, mean prediction error of $5.157 \mathrm{~mm} \mathrm{yr}^{-1}$, and root mean square prediction error of $170.9 \mathrm{~mm} \mathrm{yr}^{-1}\left(R^{2}{ }_{\text {adj. }}=60.4 \% ; P<0.001 ; n\right.$ = 269). The resulting MI map revealed a land area of $111,972 \mathrm{~km}^{2}$ (about $14 \%$ of Turkey) mostly concentrated in the Central and Southeastern Anatolia regions where moisture-related climatic conditions are not favorable for the growth of trees. 


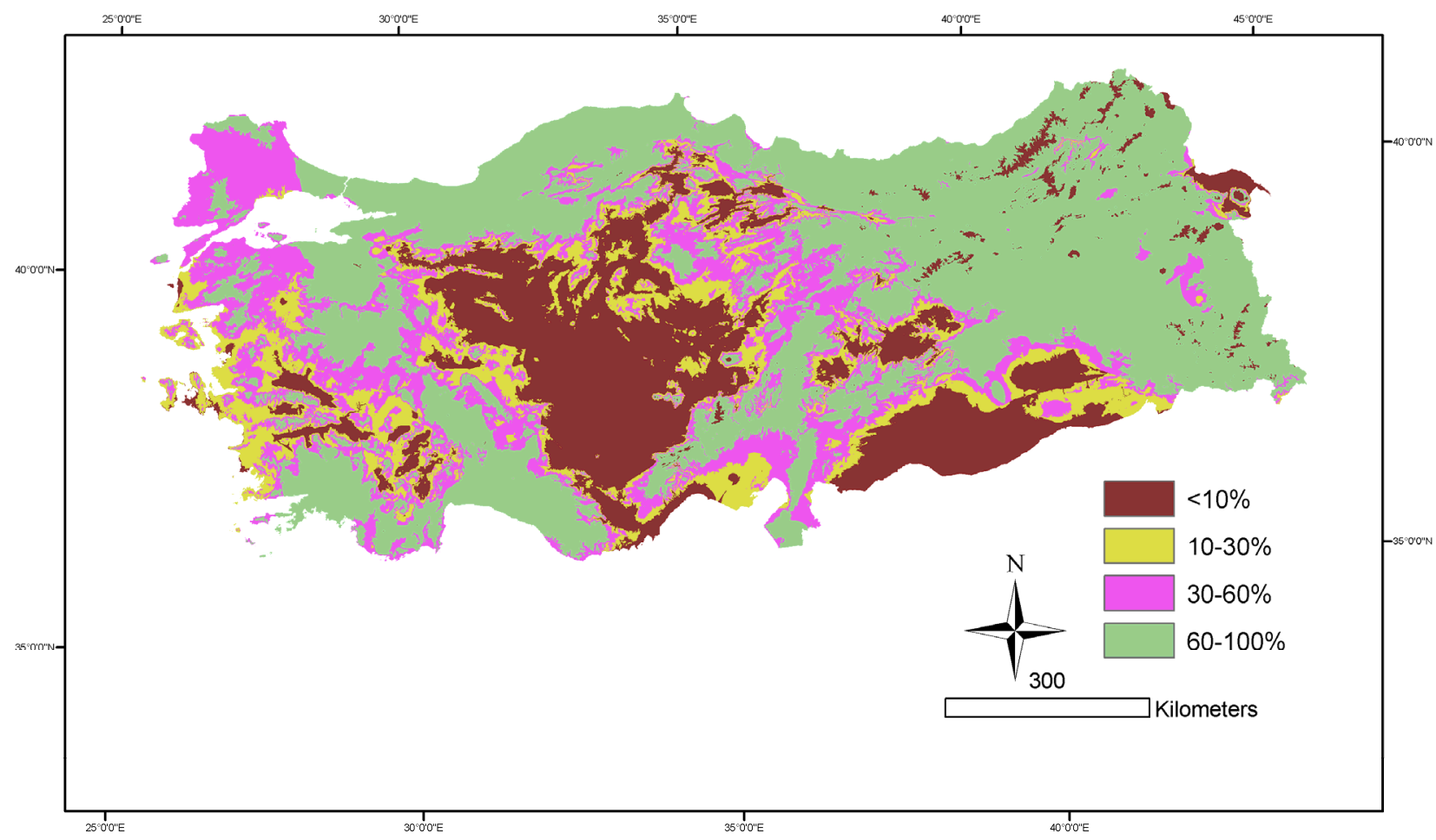

Figure 3. Spatial distribution of fractional tree cover according to the IGBP classification system.

According to the IGBP land-cover classification system, the rule-based generation of potential natural land cover map showed that forest $(f \mathrm{~T} \geq 60 \%)$, W/S $(30 \% \leq f \mathrm{~T}<60 \%)$, grassland (steppe) $(10 \% \leq f \mathrm{~T}<30 \%)$ and barren or sparsely vegetated $(f \mathrm{~T}<10 \%)$ ecosystems covered $371,097 \mathrm{~km}^{2}$ (47.5\%), 150,608 $\mathrm{km}^{2}$ (19.3\%), 96,533 $\mathrm{km}^{2}$ (12.4\%), and 162,357 km² (20.8\%) of Turkey, respectively (Table 3). Once the digital map layers of the biogeoclimate zones and the IGBP land-cover classification were overlaid, biome-specific land cover types were determined (Figure 4). Existence, fractional cover, and spatial extent of PFT mixtures (EN versus DB forests and W/S) were determined using the gradient maps of $\mathrm{MMT}_{\text {coldest }}$ and GSP (Figure 5) (Table 3). According to the relative dominance of EN versus DB trees, $63 \%, 26 \%$, and $11 \%$ of the forests appeared to be mixed (EN or DB $<70 \%$ ), EN and DB forests, respectively. Pure EN forests (EN or DB $\geq 70 \%$ ) range from boreal EN forests (e.g., Abies nordmanniana, and Picea orientalis) to Mediterranean EN forests (e.g., Pinus brutia, and Pinus pinea) along the $\mathrm{MMT}_{\text {coldest }}$ and GSP gradients across Turkey.

The MLR models by Paruelo and Lauenroth [35] of $f S$ and $f C 3$ as a function of PPT and MAT that were normalized to $f \mathrm{~T}$ were used to estimate the coexistence and fractional cover of trees, shrubs, and C3 grass in a single pixel based on the IGBP land-cover classification (Figure 1). MLR-based spatial interpolations of $\mathrm{PPT}_{\mathrm{DJF}}$ and MAT had $R^{2}$ adj. values of $73.1 \%$ as a function of LAT, LON, DEM, and DtS and $90.1 \%$ as a function of LAT, LON, DEM, DtS, and aspect, respectively $(P<0.001 ; n=265)$. Areas with $f \mathrm{~S}$ of $<20 \%, 20 \%$ to $50 \%, 50 \%$ to $80 \%$, and $>80 \%$ comprise $302,331 \mathrm{~km}^{2}(39 \%)$ of the eastern and northern Anatolia and southwestern Mediterranean regions; $120,030 \mathrm{~km}^{2}(15 \%)$ of the northwestern and central Anatolia regions; and 154,259 $\mathrm{km}^{2}(20 \%)$ and $203,975 \mathrm{~km}^{2}(26 \%)$ of the central, southeastern and western Anatolia and southeastern Mediterranean regions, respectively (Figure 6). The distribution map of C3 grass in Turkey revealed that lowland steppes are concentrated 
in the central and southeastern Anatolia regions, and the Iğdır plain in the eastern border of Turkey, while highland steppes mostly take place in the northeastern and eastern Anatolia regions (Figure 7).

Table 3. Biogeoclimatic distribution of plant functional type (PFT) mixtures according to the IGBP land-cover classification.

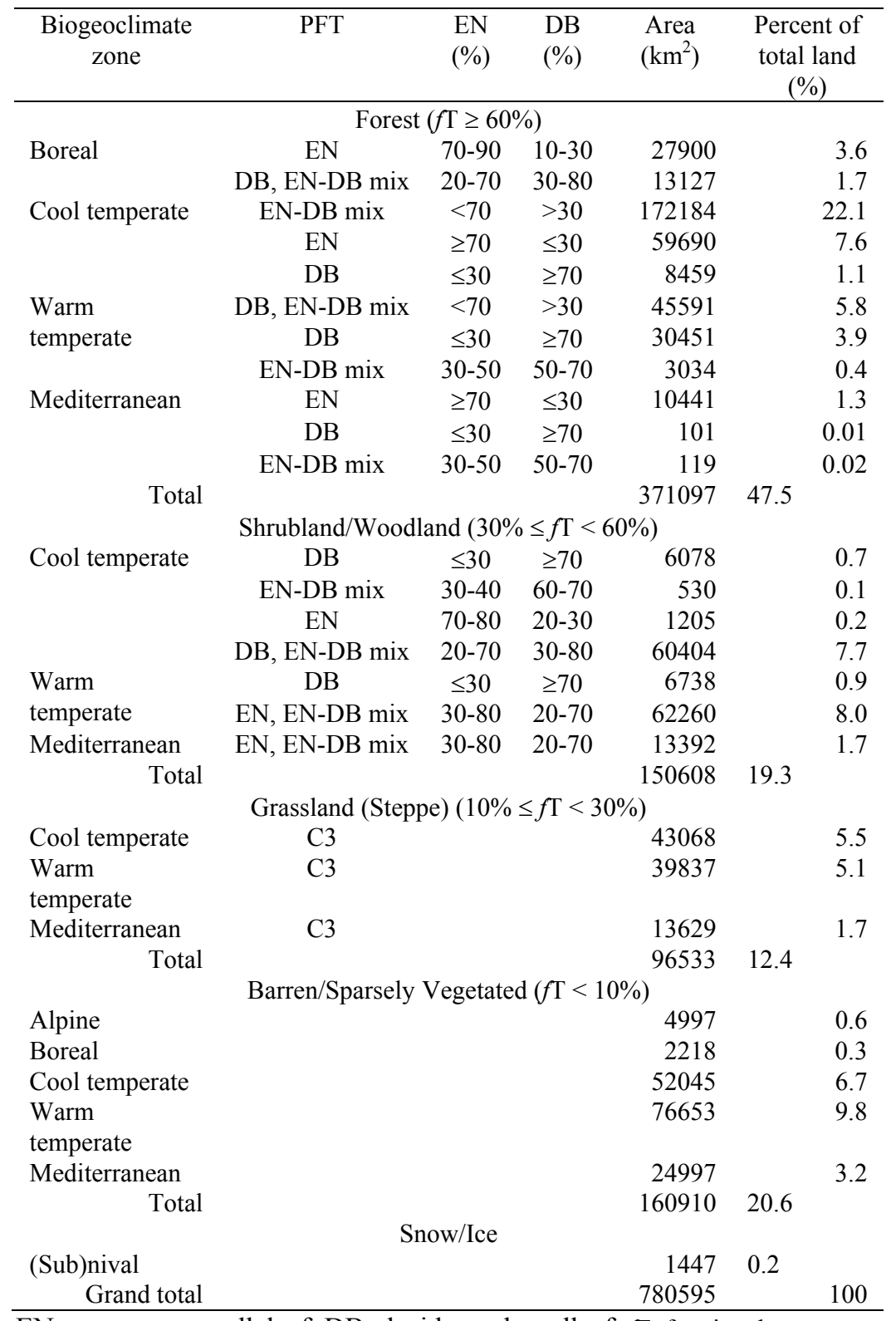

EN: evergreen needleleaf, DB: deciduous broadleaf, $f \mathrm{~T}$ : fractional tree cover. 


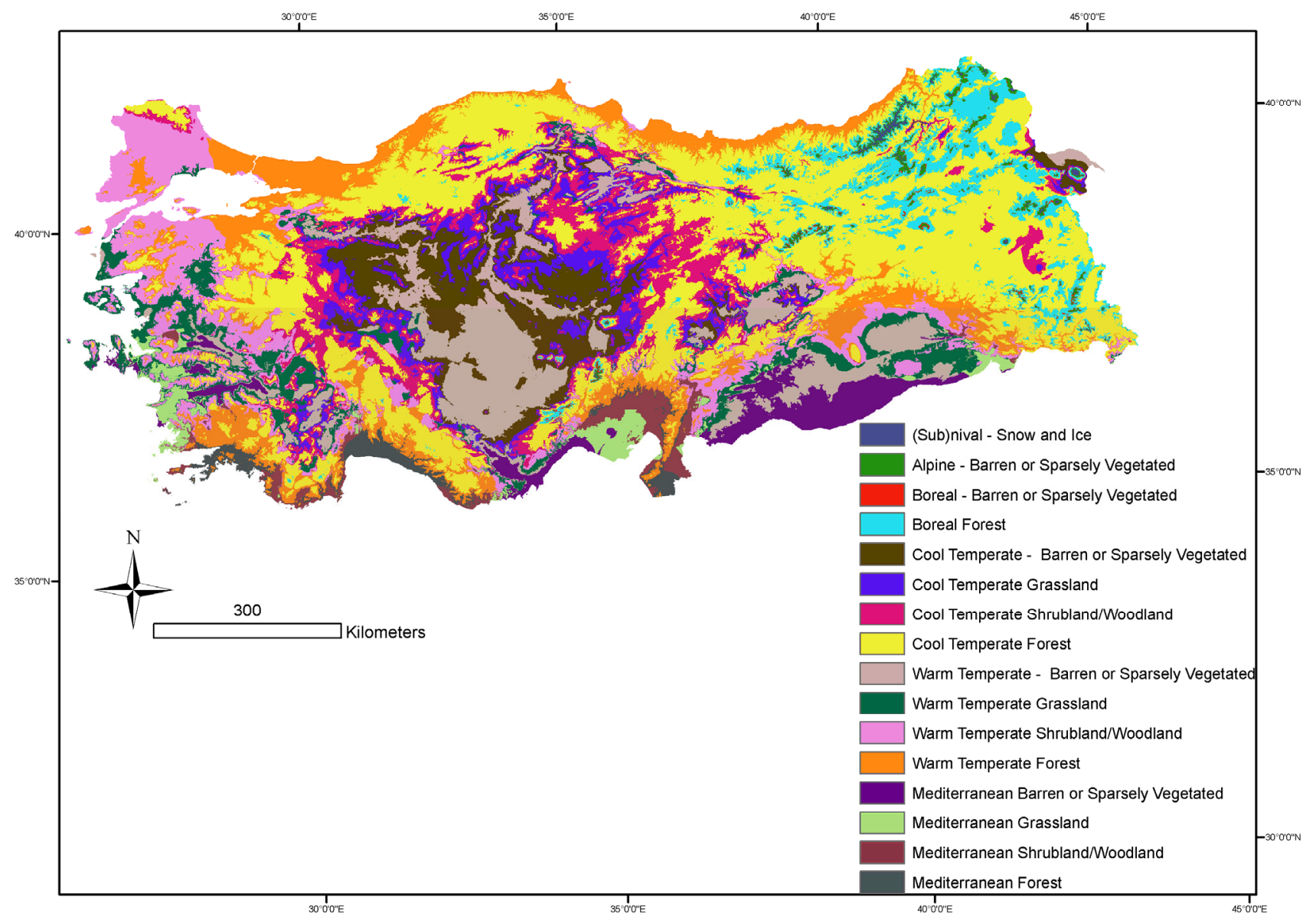

Figure 4. Land cover types in Turkey according to the IGBP classification system.

\subsection{Total Net Primary Production under Growth-Limiting and Optimal Conditions}

For each land cover type of the IGBP classification system, minimum, mean and maximum TNPP values of both mutually exclusive and inclusive PFTs under the growth-limiting and optimal environmental conditions were predicted for each pixel of $500 \mathrm{~m}$ x $500 \mathrm{~m}$ resolution based on the DECP model (Table 4). Simulations of the DECP model are based on the geographic locationsensitive spatial interpolations of the driving variables of PAR, GSL, and LCF (CLD x MI) through the following MLR models obtained:

$$
\begin{aligned}
& \mathrm{CLD}=-1.35+0.00318 \mathrm{LAT}+0.0429 \mathrm{LON}-0.00000003 \mathrm{DtS}-0.000042 \mathrm{Asp}\left(R_{\text {adj. }}^{2}=75.3 \% ; P<0.001 ;\right. \\
& \quad n=265) \\
& \mathrm{GSL}=805+4.25 \mathrm{LAT}-17.1 \mathrm{LON}-0.0946 \mathrm{DEM}-0.000099 \mathrm{DtS}\left(R_{\text {adj. }}^{2}=78.2 \% ; P<0.001 ; n=265\right) \\
& \mathrm{PAR}=20.5-0.0287 \mathrm{LAT}-0.341 \mathrm{LON}+0.00074 \mathrm{DEM}+0.00126 \mathrm{Asp}\left(R_{\text {adj. }}^{2}=47.3 \% ; P<0.001 ; n=\right.
\end{aligned}
$$

The DECP model revealed that TNPP values of mutually exclusive PFTs ranged from $108 \pm 26$ to


growth-limiting conditions for all the natural ecosystems in Turkey (Table 4). Total NPP values of


$23 \pm 8$ to $92 \pm 31 \mathrm{Tg} \mathrm{C} \mathrm{yr}^{-1}$ under the growth-limiting conditions. Forest TNPP varied between $147 \pm$ 
$41 \mathrm{~g} \mathrm{C} \mathrm{m}^{-2} \mathrm{yr}^{-1}$ in boreal EN forest and $3431 \pm 709 \mathrm{~g} \mathrm{C} \mathrm{m}^{-2} \mathrm{yr}^{-1}$ in warm temperate DB forest under the optimum conditions and between $26 \pm 11 \mathrm{~g} \mathrm{C} \mathrm{m}^{-2} \mathrm{yr}^{-1}$ in warm temperate DB forest and $240 \pm 62 \mathrm{~g} \mathrm{C}$ $\mathrm{m}^{-2} \mathrm{yr}^{-1}$ in Mediterranean EN forest under the growth-limiting conditions according to the mutually exclusive IGBP classification (Table 4).



Figure 5. Distribution of mixture of deciduous broadlead versus evergreen needleleaf forests in different biogeoclimatic zones.

Minimum and maximum TNPP values of W/S ecosystems were estimated at $87+19 \mathrm{~g} \mathrm{C} \mathrm{m}^{-2} \mathrm{yr}^{-1}$ and $1689+371 \mathrm{~g} \mathrm{C} \mathrm{m}^{-2} \mathrm{yr}^{-1}$ for warm temperate $\mathrm{DB} \mathrm{W} / \mathrm{S}$ under the optimal conditions and at $9+3 \mathrm{~g} \mathrm{C}$ $\mathrm{m}^{-2} \mathrm{yr}^{-1}$ in warm temperate DB W/S and $116+18 \mathrm{~g} \mathrm{C} \mathrm{m}^{-2} \mathrm{yr}^{-1}$ in Mediterranean EN W/S under the growth-limiting conditions, respectively. Steppe ecosystems in Turkey were estimated to have TNPP values ranging from $57+17 \mathrm{~g} \mathrm{C} \mathrm{m}^{-2} \mathrm{yr}^{-1}\left(5+2 \mathrm{~g} \mathrm{C} \mathrm{m}^{-2} \mathrm{yr}^{-1}\right.$ under the limiting conditions $)$ in the cool temperate zone to $1023+319 \mathrm{~g} \mathrm{C} \mathrm{m}^{-2} \mathrm{yr}^{-1}\left(51+18 \mathrm{~g} \mathrm{C} \mathrm{m}^{-2} \mathrm{yr}^{-1}\right.$ under the limiting conditions) in the Mediterranean zone under the optimal conditions (Table 4).

Our DECP model did not estimate any productive natural area for the mutually exclusive IGBP land cover of barren or sparsely vegetated land. However, the coexistence of PFT mixtures revealed TNPP values by the shrub and grass life forms of $39 \pm 5 \mathrm{Tg} \mathrm{C} \mathrm{yr}^{-1}$ to $211 \pm 26 \mathrm{Tg} \mathrm{C} \mathrm{yr}^{-1}$ under the optimal conditions and of $3 \pm 1 \mathrm{Tg} \mathrm{C} \mathrm{yr}^{-1}$ to $17 \pm 4 \mathrm{Tg} \mathrm{C} \mathrm{yr}^{-1}$ under the limiting conditions for the barren or sparsely vegetated ecosystems. Shrub TNPP values under the coexistence of PFTs ranged from $26 \pm 8$ $\mathrm{g} \mathrm{C} \mathrm{m}^{-2} \mathrm{yr}^{-1}$ in the (sub)nival zone to $1475 \pm 202 \mathrm{~g} \mathrm{C} \mathrm{m}^{-2} \mathrm{yr}^{-1}$ in the warm temperate steppe under the optimal conditions and from $8 \pm 2 \mathrm{~g} \mathrm{C} \mathrm{m}^{-2} \mathrm{yr}^{-1}$ in the warm temperate forest to $153 \pm 29 \mathrm{~g} \mathrm{C} \mathrm{m}^{-2} \mathrm{yr}^{-1}$ in 
the warm temperate steppe under the limiting conditions. The algorithm of the DECP model for the coexisting PFTs led to a 2.5- to 4.6-fold increase in the estimation of steppe TNPP values under the (non)-limiting conditions, relative to the algorithm for the mutually exclusive PFTs.

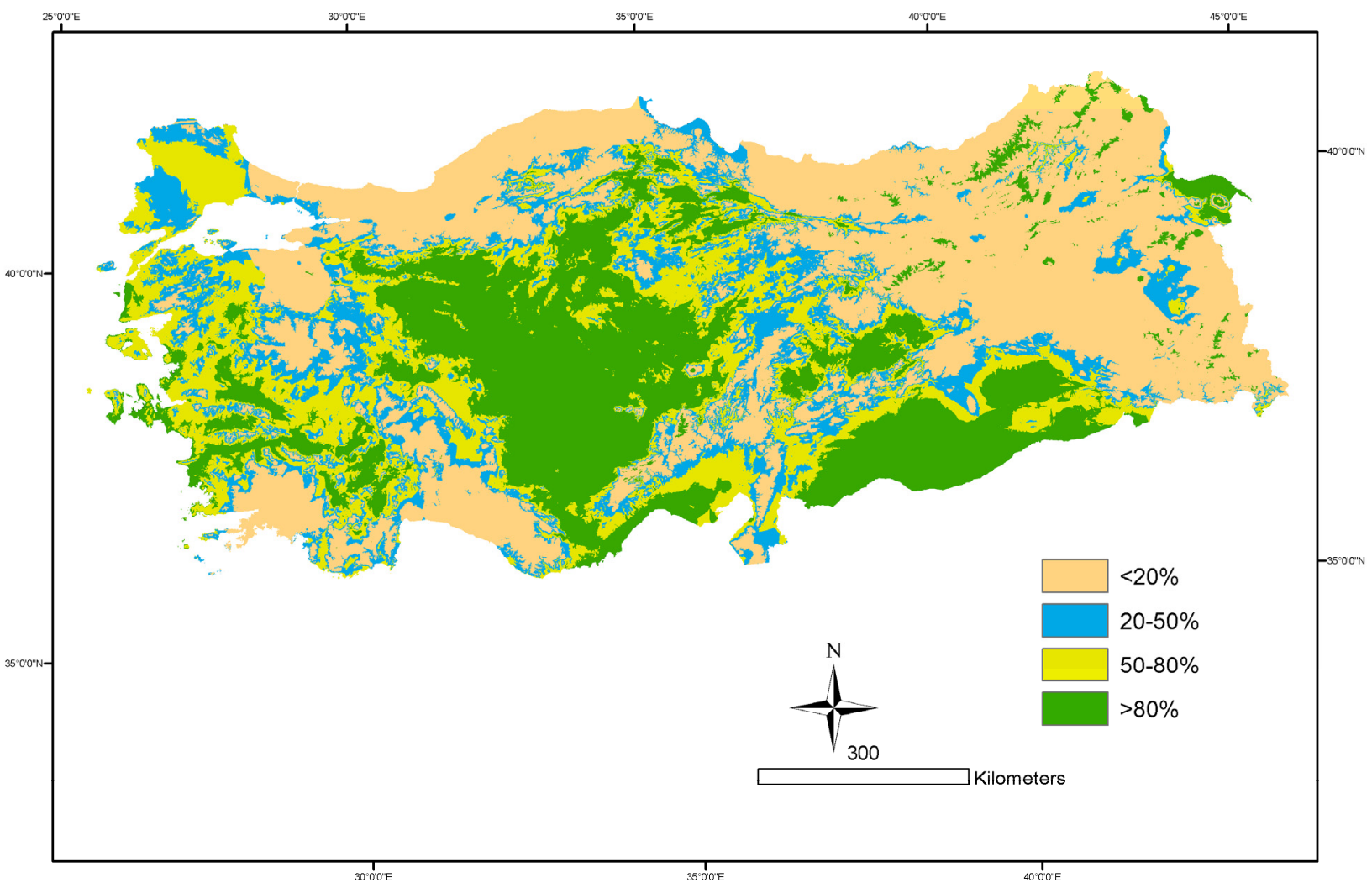

Figure 6. Spatial distribution of fractional shrub cover.

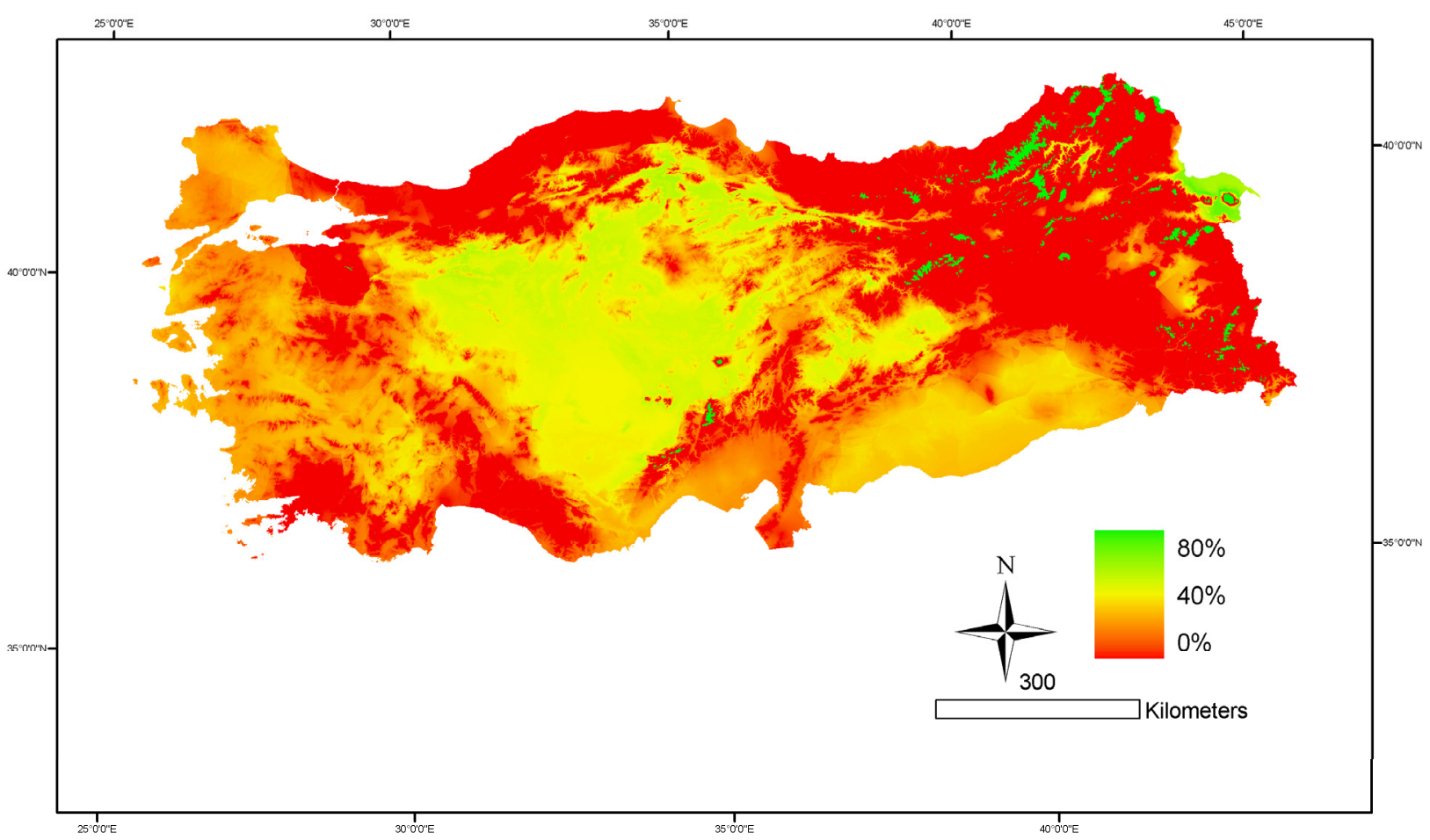

Figure 7. Spatial distribution of fractional C3 grass cover. 
Table 4. Total net primary production (TNPP, $\mathrm{g} \mathrm{C} \mathrm{m}^{-2} \mathrm{yr}^{-1}$ ) of mutually exclusive and inclusive plant functional types (PFTs) under optimal and growth-limiting conditions as determined by the DECP algorithm according to the IGBP land-cover classification [34].

\begin{tabular}{|c|c|c|c|c|c|c|c|}
\hline \multirow[t]{3}{*}{ PFTs } & \multirow[t]{3}{*}{$\begin{array}{l}\text { Area }\left(\mathrm{km}^{2}\right) \\
(\% \text { of total })\end{array}$} & \multicolumn{3}{|c|}{$\begin{array}{l}\text { TNPP under optimum conditions } \\
\left(\mathrm{g} \mathrm{C} \mathrm{m}^{-2} \mathrm{yr}^{-1}\right)\end{array}$} & \multicolumn{3}{|c|}{$\begin{array}{l}\text { TNPP under environmental limitations } \\
\qquad\left(\mathrm{g} \mathrm{C} \mathrm{m}^{-2} \mathrm{yr}^{-1}\right)\end{array}$} \\
\hline & & $\min$ & mean & $\max$ & $\min$ & mean & $\max$ \\
\hline & & \multicolumn{6}{|c|}{ Forest } \\
\hline B EN tree (IGBP) & $38236(4.9)$ & $147.4 \pm 41$ & $317.0 \pm 89$ & $758.4 \pm 215$ & $35.3 \pm 14$ & $76.0 \pm 31$ & $81.9 \pm 33$ \\
\hline B EN shrub & $221(0.03)$ & $45.6 \pm 8$ & $98.0 \pm 17$ & $105.5 \pm 19$ & $23.9 \pm 14$ & $51.3 \pm 31$ & $55.2 \pm 33$ \\
\hline $\mathrm{B}$ grass & $38236(4.9)$ & $\overline{<} 1$ & $<1$ & $<1$ & $<1$ & $<1$ & $<1$ \\
\hline \multicolumn{2}{|l|}{ Total } & $193 \pm 49$ & $415 \pm 106$ & $864 \pm 234$ & $59 \pm 28$ & $127 \pm 62$ & $137 \pm 66$ \\
\hline CT EN tree (IGBP) & $226215(29.0)$ & $280.1 \pm 69$ & $602.5 \pm 148$ & $1441.2 \pm 355$ & $45.0 \pm 19$ & $96.8 \pm 41$ & $104.2 \pm 45$ \\
\hline CT EN shrub & $41210(5.3)$ & $97.2 \pm 25$ & $209.1 \pm 53$ & $225.1 \pm 57$ & $11 . \overline{5} \pm 4$ & $24.7 \pm 8$ & $26.7 \pm 9$ \\
\hline $\mathrm{CT}$ grass & $226215(29.0)$ & $<1$ & $<1$ & $1 . \overline{9} \pm 3$ & $\overline{<} 1$ & $\overline{<} 1$ & $\overline{<} 1$ \\
\hline \multicolumn{2}{|l|}{ Total } & $377 \pm 94$ & $812 \pm 201$ & $1668 \pm \overline{415}$ & $57 \pm 23$ & $122 \pm 49$ & $131 \pm 54$ \\
\hline WT DB tree (IGBP) & $74975(9.6)$ & $175.9 \pm 36$ & $573.2 \pm 118$ & $3430.7 \pm 709$ & $25.9 \pm 11$ & $84.3 \pm 36$ & $227.2 \pm 97$ \\
\hline WT DB shrub & $23023(2.9)$ & $60.6 \pm 13$ & $197 . \overline{6} \pm 43$ & $532.0 \pm 116$ & $7 . \overline{6} \pm 2$ & $24.8 \pm 8$ & $66.8 \pm 21$ \\
\hline WT grass & $74975(9.6)$ & $<1$ & $1.5 \pm 2$ & $3.3 \pm 4$ & $<1$ & $<1$ & $<1$ \\
\hline \multicolumn{2}{|l|}{ Total } & $237 \pm 49$ & $772 \pm \overline{163}$ & $3966 \pm 829$ & $34 \pm 13$ & $109 \pm 44$ & $294 \pm 118$ \\
\hline M EN tree (IGBP) & $9658(1.2)$ & $195.5 \pm 34$ & $301 . \overline{4} \pm 52$ & $3096.3 \pm 539$ & $33 . \overline{6} \pm 8$ & $51.8+13$ & $239 . \overline{7} \pm 62$ \\
\hline M EN shrub & $3771(0$ & $72.2 \pm 14$ & $111.3 \pm 21$ & $514 . \overline{5} \pm 98$ & $11.0 \pm 2$ & $17.0 \pm 3$ & $78.5 \pm 15$ \\
\hline \multirow{2}{*}{\multicolumn{2}{|c|}{ Total }} & $1.0 \pm 1$ & $2.1 \pm 2$ & $4 . \overline{6} \pm 4$ & $\overline{<} 1$ & $<1$ & $<1$ \\
\hline & & $269 \pm 49$ & $415 \pm 75$ & $3615 \pm \overline{641}$ & $45 \pm 10$ & $69 \pm 16$ & $318 \pm 77$ \\
\hline & & \multicolumn{6}{|c|}{ Woodland/Shrubland } \\
\hline CT EN W/S (IGBP) & $64824(8.3)$ & $151.9 \pm 34$ & $326.8 \pm 74$ & $781.7 \pm 178$ & $16.2 \pm 5$ & $35.0 \pm 11$ & $37.7 \pm 12$ \\
\hline CT EN shrub & 6746 & $179.8 \pm 40$ & $386.8 \pm 86$ & $416.3 \pm 93$ & $19.0 \pm 5$ & $40.9 \pm 11$ & $43.9 \pm 12$ \\
\hline CT grass & $64824(8.3)$ & $3.2 \pm 1$ & $6.8 \pm 1$ & $14 . \overline{6} \pm 3$ & $\overline{<} 1$ & $<1$ & $1.5 \pm 0.3$ \\
\hline Maximum total & & $183 \pm 41$ & $394 \pm 87$ & $796 \pm 181$ & $19 \pm 5$ & $41 \pm 11$ & $45 \pm 12$ \\
\hline WT DB W/S (IGBP) & $65610(8.4)$ & $86.6 \pm 19$ & $282.1 \pm 62$ & $1688.7 \pm 371$ & $9.4 \pm 3$ & $30.9 \pm 10$ & $83.2 \pm 28$ \\
\hline WT DB shrub & $67866(8.7)$ & $108.6 \pm 23$ & $353.8 \pm 74$ & $952.8 \pm 200$ & $11.8 \pm 3$ & $38.6+11$ & $103.8 \pm 30$ \\
\hline WT grass & $65610(8.4)$ & $3.4 \pm 1$ & $7.2 \pm 1$ & $15.4 \pm 2$ & $<1$ & $<1$ & $1.7 \pm 0.4$ \\
\hline Maximum total & & $112 \pm 24$ & $361 \pm 75$ & $1704 \pm \overline{373}$ & $12 \pm 3$ & $39 \pm 11$ & \pm 30 \\
\hline M EN W/S (IGBP) & 6) & $02.9 \pm 21$ & $158.6 \pm 33$ & $29.5 \pm 3$ & & $21.0 \pm$ & \pm 27 \\
\hline M EN shrub & & $125.0 \pm 20$ & $192.7 \pm 31$ & $890.6 \pm 141$ & $16.3 \pm 3$ & $25.2 \pm 4$ & $116.3 \pm 18$ \\
\hline $\mathrm{M}$ grass & $12153(1.6)$ & $3 . \overline{7} \pm 1$ & $7 . \overline{8} \pm 1$ & $16.8 \pm 3$ & $\overline{<} 1$ & $1.0 \pm \overline{0} .1$ & $2.2 \pm 0.2$ \\
\hline \multirow[t]{2}{*}{ Maximum total } & & $129 \pm 21$ & $201 \pm 32$ & $1646 \pm 346$ & $16 \pm 3$ & $26 \pm 4$ & $119 \pm 18$ \\
\hline & & \multicolumn{6}{|c|}{ Grassland (Steppe) } \\
\hline CT grassland (IGBP) & $40981(5.3)$ & $57.3 \pm 17$ & $120.5 \pm 36$ & $576.0 \pm 175$ & $5.3 \pm 2$ & $11.3 \pm 4$ & $24.3 \pm 9$ \\
\hline CT shrub & 4 & $276.3 \pm 38$ & $594.2 \pm 82$ & $639.7 \pm 88$ & $25.6 \pm 5$ & $55.2 \pm 11$ & $59.3 \pm 13$ \\
\hline $\mathrm{CT}$ grass & $40981(5.3)$ & $4.7 \pm 1$ & $9.8 \pm 1$ & $21.0 \pm 3$ & $\overline{<} 1$ & $<1$ & $1.9 \pm 0.2$ \\
\hline Max & & $334 \pm 55$ & $715 \pm \overline{118}$ & $216 \pm \overline{263}$ & 7 & $67 \pm 15$ & $84 \pm 22$ \\
\hline WT grassla & & \pm 24 & 1 & 849.4 & & $18.5 \pm 6$ & \pm 13 \\
\hline WT shrub & & $168.1 \pm 23$ & $547.7 \pm 75$ & $1475.1 \pm 2$ & $17.5 \pm 4$ & $56.8 \pm 11$ & \pm 29 \\
\hline WT grass & $37202(4.8)$ & $4 . \overline{9} \pm 1$ & $10 . \overline{3} \pm 1$ & $22 . \overline{2} \pm 2$ & $\overline{<} 1$ & $1.0 \pm 0.2$ & $2.3 \pm 0.3$ \\
\hline Maxim & & $253 \pm 47$ & $665 \pm 126$ & $2325 \pm 449$ & $26 \pm 7$ & $75 \pm 17$ & $193 \pm 42$ \\
\hline M grassland (IGBP) & $12439(1.6)$ & $101.8 \pm 31$ & $213.9 \pm 66$ & $1022.5 \pm 319$ & $11.3 \pm 4$ & $23.9 \pm 8$ & $51.4 \pm 18$ \\
\hline M shrub & 13201(1.7) & $175.8 \pm 22$ & $271.1 \pm 34$ & $1252.8 \pm 157$ & $19.5 \pm 3$ & $30.0 \pm 5$ & $138.7 \pm 19$ \\
\hline $\mathrm{M}$ grass & $12439(1.6)$ & $5.2 \pm 0.4$ & $11.0 \pm 1$ & $23.7 \pm 2$ & $<1$ & $1.2 \pm 0.1$ & $2.6 \pm 0.2$ \\
\hline \multicolumn{2}{|l|}{ Maximum total } & $277 \pm 53$ & $485 \pm \overline{100}$ & $2275 \pm \overline{476}$ & $31 \pm 7$ & $54 \pm 13$ & $190 \pm 37$ \\
\hline & & \multicolumn{6}{|c|}{ Barren/Sparsely Vegetated Land } \\
\hline $\operatorname{Sub}($ & & $25.7 \pm$ & 8 & 59.4 & & $8.7 \pm$ & $0.9 \pm 20$ \\
\hline Sub(nival) grass & $1361(0.2)$ & $2.7 \pm 1$ & $5 . \overline{6} \pm 3$ & $12.0 \pm 6$ & $1.4 \pm 1$ & $2.9 \pm 2$ & $6.3 \pm 5$ \\
\hline Total & & $28 \pm 9$ & $61 \pm \overline{2} 1$ & $71 \pm 25$ & $15 \pm \overline{10}$ & $32 \pm-20$ & $37 \pm 25$ \\
\hline Alpine shrub & $4855(0.6)$ & $45.5 \pm 23$ & $97.9 \pm 50$ & $105.4 \pm 54$ & $18.7 \pm 15$ & $40.2 \pm 33$ & $43.3 \pm 36$ \\
\hline Alpine grass & $4684(0.6)$ & $3.1 \pm 2$ & $6.6 \pm 4$ & $14.2 \pm 10$ & $1.3 \pm 1$ & $2.7 \pm 3$ & $6.0 \pm 6$ \\
\hline Total & & $49 \pm 25$ & $105 \pm 54$ & $130 \pm 64$ & $20 \pm 16$ & $43 \pm 36$ & $49 \pm 42$ \\
\hline B shrub & 206 & $62.6 \pm 28$ & $134.7 \pm 59$ & $145.0 \pm 64$ & $24.0 \pm 15$ & $51.6 \pm 33$ & $55.5 \pm 35$ \\
\hline $\mathrm{B}$ grass & $2066(0.3)$ & $3.1 \pm 2$ & $6 . \overline{5} \pm 4$ & $14.0 \pm 10$ & $1.2 \pm 1$ & $2.5 \pm 2$ & $5.6 \pm 5$ \\
\hline Total & & $66 \pm 30$ & $141 \pm 63$ & $159 \pm 74$ & $25 \pm 16$ & $54 \pm 35$ & $61 \pm 40$ \\
\hline $\mathrm{CTs}$ & & $355.9 \pm 33$ & $765.4 \pm 72$ & $823.9 \pm 77$ & $28.9 \pm 4$ & $62.3 \pm 9$ & $67.2 \pm 10$ \\
\hline CT grass & $49423(6.3)$ & $5 . \overline{6} \pm 1$ & $11.8 \pm 1$ & $25 . \overline{4} \pm 2$ & $\overline{<} 1$ & $0.9 \pm \overline{0} .1$ & $2.1 \pm 0.2$ \\
\hline Total & & $402 \pm 34$ & $777 \pm 73$ & $849 \pm 79$ & $29 \pm 4$ & $6 \overline{3} \pm 9$ & $69 \pm 10$ \\
\hline WT shrub & $75665(9.7)$ & $192.6 \pm 28$ & $627.5 \pm 90$ & $1689.9 \pm 242$ & $15.4 \pm 4$ & $50.1 \pm 14$ & $134.7 \pm 36$ \\
\hline WT grass & $71814(9.2)$ & $6.1 \pm 0.5$ & $12.8 \pm 1$ & $27.4+2$ & $0.5 \pm \overline{0} .1$ & $1.0 \pm 0.2$ & $2.2 \pm 0.4$ \\
\hline
\end{tabular}




\begin{tabular}{|c|c|c|c|c|c|c|c|}
\hline \multicolumn{2}{|l|}{ Total } & $199 \pm 29$ & $640 \pm 91$ & $1717 \pm 244$ & $16 \pm 4$ & $51 \pm 14$ & $137 \pm 36$ \\
\hline M shrub & $24396(3.1)$ & $206.4 \pm 17$ & $318.1 \pm 26$ & $1470.3 \pm 121$ & $17.4 \pm 3$ & $26.9 \pm 5$ & $124.1 \pm 21$ \\
\hline \multirow[t]{3}{*}{ M grass } & $22572(2.9)$ & $6.5 \pm 0.4$ & $13 . \overline{6} \pm 1$ & $29.2+2$ & $<1$ & $1.1 \pm 0.2$ & $2.5 \pm 0.4$ \\
\hline & & $213 \pm 17$ & $332 \pm 27$ & $1500 \pm \overline{123}$ & $17 \pm 3$ & $2 \overline{8} \pm 5$ & $127 \pm 21$ \\
\hline & \multicolumn{7}{|c|}{ Grand total $\left(\overline{T g} \mathrm{C} \mathrm{yr}^{-1}\right)$ of mutually exclusive PFTs } \\
\hline IGBP forest & $349084(44.7)$ & $84 \pm 20$ & $194 \pm 46$ & $642 \pm 147$ & $14 \pm 6$ & $32 \pm 14$ & $46 \pm 19$ \\
\hline IGBP W/S & $142587(18.3)$ & $1 \overline{7} \pm 4$ & $42 \pm 9$ & $181 \pm 40$ & $2 \pm 1$ & $\overline{5}+2$ & $9 \pm 3$ \\
\hline IGBP grassland & $90622(11.6)$ & $7 \pm 2$ & $14 \pm 4$ & $68 \pm 20$ & $0.7 \pm \overline{0} .2$ & $1.5 \pm 0.5$ & $3 \pm 1$ \\
\hline Grand total IGBP & $582293(74.6)$ & $108 \pm 26$ & $250 \pm 60$ & $891 \pm 207$ & $1 \overline{6} \pm 7$ & $38 \pm 16$ & $58 \pm 23$ \\
\hline Total shrub & $471440(60.0)$ & $86 \pm 13$ & $212 \pm 33$ & $437 \pm 67$ & $8 \pm 2$ & $20 \pm 5$ & $41 \pm 10$ \\
\hline \multirow[t]{2}{*}{ Total grass } & $734212(94.0)$ & $1.9 \pm 0.3$ & $3.8 \pm 0.6$ & $8.7 \pm 1.3$ & $0.2 \pm \overline{0} .1$ & $0.4 \pm \overline{0} .1$ & $0.9 \pm 0.3$ \\
\hline & \multicolumn{7}{|c|}{ Grand total (Tg C $\left.\mathrm{yr}^{-1}\right)$ of mutually inclusive PFTs } \\
\hline Total forest & $349084(44.7)$ & $90 \pm 22$ & $208 \pm 50$ & $666 \pm 153$ & $15 \pm 6$ & $33 \pm 14$ & $49 \pm 20$ \\
\hline Total W/S & $148370(19)$ & $22 \pm 5$ & $54 \pm 11$ & $18 \overline{4} \pm 40$ & $2 \pm 1$ & $\overline{6} \pm 2$ & $1 \overline{2} \pm 3$ \\
\hline Total grassland & $94944(12.2)$ & $27 \pm 5$ & $65 \pm 11$ & $170 \pm 34$ & $3+1$ & $6 \pm \overline{+} 1$ & $13 \pm 3$ \\
\hline Total BSVL & $159904(20.5)$ & $39 \pm 5$ & $97 \pm 12$ & $211 \pm 26$ & $3 \pm 1$ & $8 \pm 2$ & $17 \pm 4$ \\
\hline Grand total & & $178+36$ & $424 \pm 84$ & $1231+253$ & $23 \pm 8$ & $54 \pm 19$ & $92+31$ \\
\hline
\end{tabular}

TNPP: total net primary productivity, B: boreal, CT: cool temperate, WT: warm temperate, M: Mediterranean, EN: evergreen needleleaf, DB: deciduous broadleaf, W/S: woodland/shrubland, BSVL: barren or sparsely vegetated land. Rows designated with and without the term "IGBP" indicate values estimated according to mutually exclusive and inclusive algorithms using the IGBP land-cover classification and MLR models by Paruelo and Lauenroth [35], respectively. Values given as mean \pm standard deviation may not total due to rounding.

The DECP model estimated the areal extent of productive forest ecosystems as $349,084 \mathrm{~km}^{2}(44.7 \%$ of the entire country). Total spatial extent of productive steppe ecosystems was estimated as about $12 \%$ of the total land area based on the IGBP classification of mutually exclusive and inclusive PFTs with the fractional cover of $10 \%$ to $30 \%$ and as $94 \%$ of the total land area based on the MLR model [35] with the fractional cover less than $10 \%$. Productive W/S ecosystems occupied $18 \%$ to $19 \%$ of the total land area with the fractional cover rule (30\% to 60\%) of the IGBP classification and $60 \%$ the total land area with the fractional cover range of $0 \%$ to $100 \%$ (Table 4 ).

Based on the IDW interpolation of PPT, the modified Miami model [42] was used to estimate mean TNPP values of biogeoclimatic land cover types under the optimal conditions (Table 5). Mean TNPP values estimated by the modified Miami model across Turkey ranged from $427 \pm 100 \mathrm{~g} \mathrm{C} \mathrm{m}^{-2} \mathrm{yr}^{-1}$ in boreal forest to $653 \pm 49 \mathrm{~g} \mathrm{C} \mathrm{m}^{-2} \mathrm{yr}^{-1}$ in Mediterranean forest; from $359 \pm 30 \mathrm{~g} \mathrm{C} \mathrm{m}^{-2} \mathrm{yr}^{-1}$ in cool temperate W/S to $564 \pm 30 \mathrm{~g} \mathrm{C} \mathrm{m}^{-2} \mathrm{yr}^{-1}$ in Mediterranean W/S; and from $335 \pm 20 \mathrm{~g} \mathrm{C} \mathrm{m}^{-2} \mathrm{yr}^{-1}$ in cool temperate steppe to $499 \pm 28 \mathrm{~g} \mathrm{C} \mathrm{m}^{-2} \mathrm{yr}^{-1}$ in Mediterranean steppe (Table 5). Sub(nival) vegetation type was estimated to have the second highest TNPP of $584 \pm 200 \mathrm{~g} \mathrm{C} \mathrm{m}^{-2} \mathrm{yr}^{-1}$ after that of Mediterranean forest.

\subsection{Soil Organic Carbon Density}

Steady state SOC density for a depth of $1 \mathrm{~m}$ based on the potential distribution patterns of TNPP and biogeoclimate zones, and the gradients of BT, MAT, and PPT was lowest in warm temperate forest $\left(3.5 \pm 0.7 \mathrm{~kg} \mathrm{C} \mathrm{m}^{-3} \mathrm{yr}^{-1}\right)$ and $\mathrm{W} / \mathrm{S}\left(1.9 \pm 0.4 \mathrm{~kg} \mathrm{C} \mathrm{m}^{-3} \mathrm{yr}^{-1}\right)$, and cool temperate steppe $(1.3 \pm 0.4$ $\left.\mathrm{kg} \mathrm{C} \mathrm{m}^{-3} \mathrm{yr}^{-1}\right)$ and highest in warm temperate forest $\left(31 \pm 7 \mathrm{~kg} \mathrm{C} \mathrm{m}^{-3} \mathrm{yr}^{-1}\right)$ and W/S $\left(17 \pm 4 \mathrm{~kg} \mathrm{C} \mathrm{m}^{-3} \mathrm{yr}^{-}\right.$ $\left.{ }^{1}\right)$, and Mediterranean steppe $\left(11 \pm 3 \mathrm{~kg} \mathrm{C} \mathrm{m}^{-3} \mathrm{yr}^{-1}\right)$ under the optimal conditions. Under the limiting conditions, SOC storage ranges from $0.5 \pm 0.2 \mathrm{~kg} \mathrm{C} \mathrm{m}^{-3} \mathrm{yr}^{-1}$ in warm temperate forest to $4.7 \pm 0.9 \mathrm{~kg} \mathrm{C}$ $\mathrm{m}^{-3} \mathrm{yr}^{-1}$ in Mediterranean forest; from $0.2+0.07 \mathrm{~kg} \mathrm{C} \mathrm{m}^{-3} \mathrm{yr}^{-1}$ in warm temperate W/S to $2.2 \pm 0.6 \mathrm{~kg}$ $\mathrm{C} \mathrm{m}^{-3} \mathrm{yr}^{-1}$ in Mediterranean W/S; and from $0.1 \pm 0.04 \mathrm{~kg} \mathrm{C} \mathrm{m}^{-3} \mathrm{yr}^{-1}$ in cool temperate steppe to $1.2 \pm$ $0.4 \mathrm{~kg} \mathrm{C} \mathrm{m}^{-3} \mathrm{yr}^{-1}$ in Mediterranean steppe (Table 6). 
Table 5. Total net primary productivity (TNPP, $\mathrm{g} \mathrm{C} \mathrm{m}^{-2} \mathrm{yr}^{-1}$ ) and soil organic carbon ( $\mathrm{SOC}, \mathrm{kg} \mathrm{C} \mathrm{m}^{-3}$ ) density ( 0 to $100 \mathrm{~cm}$ in depth) under optimal conditions based on Miami model modified by Friedlingstein et al. [42].

\begin{tabular}{|c|c|c|c|}
\hline $\begin{array}{l}\text { Biogeoclimate } \\
\text { zone }\end{array}$ & $\begin{array}{l}\text { Area }\left(\mathrm{km}^{2}\right) \\
(\% \text { of total })\end{array}$ & $\begin{array}{c}\text { TNPP } \\
\left(\mathrm{g} \mathrm{C} \mathrm{m}^{-2} \mathrm{yr}^{-1}\right)\end{array}$ & $\begin{array}{c}\mathrm{SOC} \\
\left(\mathrm{kg} \mathrm{C} \mathrm{m}^{-3}\right)\end{array}$ \\
\hline & & Forest & \\
\hline Boreal & $41027(5.3)$ & $426.6 \pm 100$ & $12.4 \pm 7.8$ \\
\hline Cool temperate & $240333(30.8)$ & $455 . \overline{1} \pm 97$ & $9.5 \pm 3.8$ \\
\hline Warm temperate & $79075(10.1)$ & $569.4+90$ & $11.6 \pm 3.3$ \\
\hline \multirow[t]{2}{*}{ Mediterranean } & $10660(1.4)$ & $652.8 \pm 49$ & $13.1 \pm 1.0$ \\
\hline & $371097(48)$ & $\begin{array}{c}780.8 \pm 124 \overline{\mathrm{Tg} \mathrm{C}} \\
\text { Woodland/Shrubland }\end{array}$ & $17.3 \pm 5 \overline{\mathrm{P}} \mathrm{g} \mathrm{C}$ \\
\hline Cool temperate & $68217(8.7)$ & $358.8 \pm 30$ & $8.1 \pm 0.6$ \\
\hline Warm temperate & $68998(8.8)$ & $456.0+27$ & $10.4+0.5$ \\
\hline \multirow[t]{2}{*}{ Mediterranean } & 13392(1.7) & $564.2 \pm 30$ & $12.8+0.6$ \\
\hline & $150608(19)$ & $\begin{array}{c}207.7 \pm 13 \text { Tg C } \\
\text { Grassland (Steppe) }\end{array}$ & $4.7 \pm 0.3 \overline{P g} \mathrm{C}$ \\
\hline Cool temperate & $43068(5.5)$ & $334.5 \pm 20$ & $7.9 \pm 0.4$ \\
\hline Warm temperate & $39837(5.1)$ & $425.9 \pm 29$ & $10.1 \pm 0.6$ \\
\hline \multirow[t]{3}{*}{ Mediterranean } & $13629(1.7)$ & $498.8+28$ & $11.9+0.6$ \\
\hline & $96533(12)$ & $121.6 \pm 7 \overline{\mathrm{Tg} C}$ & $2.9 \pm 0.2 \overline{P g C}$ \\
\hline & Barr & n/Sparsely Vegetated & and \\
\hline Sub(nival) & $1447(0.2)$ & $583.5 \pm 200$ & $32.6 \pm 20.5$ \\
\hline Alpine & 4997(0.6) & $480.4+154$ & $21.7+16.1$ \\
\hline Boreal & $2218(0.3)$ & $451.6+116$ & $18.3+11.5$ \\
\hline Cool temperate & $52045(6.7)$ & $306.0 \pm 19.6$ & $7 . \overline{6}+0.3$ \\
\hline Warm temperate & $76653(9.8)$ & $326.0+52$ & $8.4+1.0$ \\
\hline Mediterranean & $24997(3.2)$ & $380.4 \pm 51$ & $10.0 \pm 0.8$ \\
\hline Total & $162357(21)$ & $410.4+96 \overline{\mathrm{Tg} C}$ & $16.0 \pm 8 \overline{\mathrm{Pg} \mathrm{C}}$ \\
\hline Grand Total (Pg C yr $\left.{ }^{-1}\right)$ & $780595(100)$ & $1.5+0.2$ & $40.9+14$ \\
\hline
\end{tabular}

Estimates of the modified Miami model for steady state amount of SOC storage range from $9.5+$ $3.8,8.1+0.6$ and $7.9+0.4 \mathrm{~kg} \mathrm{C} \mathrm{m}^{-3} \mathrm{yr}^{-1}$ in cool temperate forest, W/S and steppe to $13.1+1,12.8+$ 0.6 and $11.9+0.6 \mathrm{~kg} \mathrm{C} \mathrm{m}^{-3} \mathrm{yr}^{-1}$ in Mediterranean forest, W/S and steppe, respectively (Table 5). The national steady state SOC pool in the surface one meter of soil was estimated to range from $7.5+1.8$

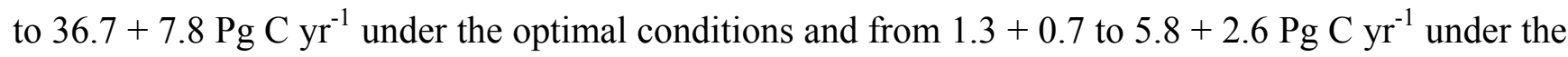
limiting conditions, based on the DECP model. The modified Miami model estimated, on average, potential SOC storage of $40.9+14 \mathrm{Pg} \mathrm{C} \mathrm{yr}^{-1}$ including the amount of SOC stored in barren or sparsely vegetated land cover.

\section{Discussion}

The proposed DECP algorithm links patterns of land cover and potential natural vegetation dynamics to changes in NPP and steady state SOC density on the national scale. Biogeoclimatic classification of the DECP model appears to represent distribution, spatial extent, and mosaics of potential natural PFTs of Turkey in harmony with evident differences in long-term mean climate data rendered sensitive to the geographic gradients of elevation, latitude, longitude, aspect, and distance to sea through MLR-based spatial interpolations. Classification accuracy of the DECP model is a function of the classification categories as well as quality of the source data used to derive biogeoclimate indices and MLR models. Spatial extent of potential natural forest ecosystems of 
$349,084 \mathrm{~km}^{2}$ estimated by the DECP model is about $64 \%$ greater than the actual forest area of 212,000 $\mathrm{km}^{2}$ reported for Turkey [53].

Table 6. Soil organic carbon (SOC, $\mathrm{kg} \mathrm{C} \mathrm{m}^{-3}$ ) density ( 0 to $100 \mathrm{~cm}$ in depth) under optimal and limiting conditions based on the DECP model according to the IGBP land-cover classification [34].

\begin{tabular}{|c|c|c|c|c|c|c|c|}
\hline \multirow[t]{2}{*}{$\begin{array}{l}\text { Biogeoclimate } \\
\text { zone }\end{array}$} & \multirow[t]{2}{*}{$\begin{array}{l}\text { Area }\left(\mathrm{km}^{2}\right) \\
(\% \text { of total })\end{array}$} & \multicolumn{3}{|c|}{$\begin{array}{l}\text { SOC under optimal conditions } \\
\left(\mathrm{kg} \mathrm{C} \mathrm{m}^{-3}\right)\end{array}$} & \multicolumn{3}{|c|}{$\begin{array}{l}\text { SOC under limiting conditions } \\
\left(\mathrm{kg} \mathrm{C} \mathrm{m}^{-3}\right)\end{array}$} \\
\hline & & $\min$ & mean & $\max$ & $\min$ & mean & $\max$ \\
\hline & & \multicolumn{6}{|c|}{ Forest } \\
\hline Boreal & $38236(4.9)$ & $4.0 \pm 1.4$ & $8.6+3.1$ & $9.2+3.4$ & $1.0 \pm 0.9$ & $2.2+1.9$ & $2.4 \pm 2.1$ \\
\hline Cool temperate & $226215(29.0)$ & $5.7 \pm 1.5$ & $12.4 \pm 3.3$ & $13.3 \pm 3.6$ & $0.9 \pm 0.5$ & $2.0 \pm 1.2$ & $2.1 \pm 1.3$ \\
\hline Warm temperate & $74975(9.6)$ & $3.5 \pm 0.7$ & $11.5 \pm 2.4$ & $31.1 \pm 6.5$ & $0.5 \pm 0.2$ & $1.7 \pm 0.8$ & $4.6 \pm 2.2$ \\
\hline Mediterranean & $9658(1.2)$ & $3.8 \pm 0.4$ & $6.0 \pm 0.7$ & $27.7 \pm 3.5$ & $0.6 \pm 0.1$ & $1.0 \pm 0.2$ & $4.7 \pm 0.9$ \\
\hline Total (Pg C) & $349084(44.7)$ & $5.9 \pm 1.4$ & $13.4 \pm 3.3$ & $28.4 \pm 5.9$ & $1.1 \pm 0.7$ & $2.4 \pm 1.5$ & $4.9 \pm 2.3$ \\
\hline & & \multicolumn{6}{|c|}{ Woodland/Shrubland } \\
\hline Cool temperate & $64824(8.3)$ & $3.4 \pm 0.7$ & $7.4 \pm 1.6$ & $8.0 \pm 1.7$ & $0.3 \pm 0.1$ & $0.7 \pm 0.2$ & $0.8 \pm 0.2$ \\
\hline Warm temperate & $65610(8.4)$ & $1.9 \pm 0.4$ & $6.4 \pm 1.3$ & $17.3 \pm 3.6$ & $0.2 \pm 0.07$ & $0.7 \pm 0.2$ & $1.8 \pm 0.6$ \\
\hline Mediterranean & $12153(1.6)$ & $2.3 \pm 0.4$ & $3.6 \pm 0.7$ & $16.6 \pm 3.3$ & $0.3 \pm 0.08$ & $0.4 \pm 0.1$ & $2.2 \pm 0.6$ \\
\hline Total $(\operatorname{Pg~C})$ & $142587(18.3)$ & $1.1 \pm 0.2$ & $2.5 \pm 0.5$ & $6.0 \pm 1.2$ & $0.1 \pm 0.04$ & $0.3 \pm 0.1$ & $0.7 \pm 0.2$ \\
\hline & & \multicolumn{6}{|c|}{ Grassland (Steppe) } \\
\hline Cool temperate & 40981(5.3) & $1.3 \pm 0.4$ & $2.8 \pm 0.8$ & $6.1 \pm 1.8$ & $0.1 \pm 0.04$ & $0.2 \pm 0.09$ & $0.5 \pm 0.2$ \\
\hline Warm temperate & 37202(4.8) & $2.0 \pm 0.5$ & $4.2 \pm 1.1$ & $9.0 \pm 2.5$ & $0.2 \pm 0.07$ & $0.4 \pm 0.1$ & $0.9 \pm 0.3$ \\
\hline Mediterranean & $12439(1.6)$ & $2.4 \pm 0.7$ & $5.1 \pm 1.5$ & $10.9 \pm 3.3$ & $0.2 \pm 0.09$ & $0.5 \pm 0.1$ & $1.2 \pm 0.4$ \\
\hline Total (Pg C) & $90622(11.6)$ & $0.5 \pm 0.1$ & $1.1 \pm 0.3$ & $2.4 \pm 0.7$ & $0.1 \pm 0.02$ & $0.1 \pm 0.04$ & $0.2 \pm 0.1$ \\
\hline Grand Total $(\operatorname{Pg~C})$ & $582293(74.6)$ & $7.5 \pm 1.8$ & $17.0 \pm 4.1$ & $36.7 \pm 7.8$ & $1 . \overline{3}+0.7$ & $2 . \overline{8}+1.6$ & $5.8 \pm 2.6$ \\
\hline
\end{tabular}

Values given as mean \pm standard deviation may not total due to rounding.

Literature compilations by Ruimy et al. [40] of biome-specific TNPP values indicated ranges of 100 to $2000 \mathrm{~g} \mathrm{C} \mathrm{m}^{-2} \mathrm{yr}^{-1}$ for Mediterranean forest, 100 to $900 \mathrm{~g} \mathrm{C} \mathrm{m}^{-2} \mathrm{yr}^{-1}$ for temperate forest, 100 to $800 \mathrm{~g}$ $\mathrm{C} \mathrm{m}^{-2} \mathrm{yr}^{-1}$ for boreal forest, 20 to $1500 \mathrm{~g} \mathrm{C} \mathrm{m}^{-2} \mathrm{yr}^{-1}$ for W/S of all latitudes, 50 to $2000 \mathrm{~g} \mathrm{C} \mathrm{m}^{-2} \mathrm{yr}^{-1}$ for temperate grassland, and 20 to $300 \mathrm{~g} \mathrm{C} \mathrm{m}^{-2} \mathrm{yr}^{-1}$ for tundra grassland. The range of TNPP estimates, particularly under the optimal conditions, by the DECP model and the modified Miami model agrees well with the minimum and maximum values of TNPP estimated in the literature compilations of TNPP by Ruimy et al. [40]. Our comparisons for different land cover types show that the DECP model estimates of TNPP fall within the ranges of the MODIS-derived computations of NPP by Running et al. [49] and existing field data by Kucharik et al. [50] and Zheng et al. [11]. On the national scale, minimum TNPP (16 Tg C $\mathrm{yr}^{-1}$ ) of mutually exclusive PFTs under the limiting conditions and

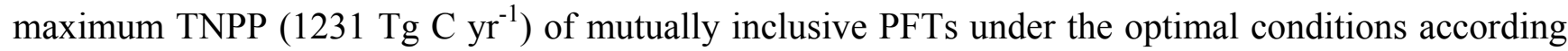


conditions according to the modified Miami model elucidate $0.02 \%, 2.0 \%$, and $2.5 \%$ of the global mean TNPP value of $59 \mathrm{Pg} \mathrm{C} \mathrm{yr}^{-1}$.

The DECP model predicted SOC storage patterns across the biogeoclimate zones and PFTs of Turkey similar to those revealed by global SOC dataset derived from potential natural vegetationsupporting soil profiles and classified according to HLZ [48]. Global SOC data by Post et al. [48] showed $9.2 \pm 4.5 \mathrm{~kg} \mathrm{C} \mathrm{m}^{-3}$ for Mediterranean moist forest, $11.5 \pm 13.9 \mathrm{~kg} \mathrm{C} \mathrm{m}^{-3}$ for Mediterranean dry forest, $5.4 \pm 2.2 \mathrm{~kg} \mathrm{C} \mathrm{m}^{-3}$ for Mediterranean W/S, $9.3 \pm 7.4 \mathrm{~kg} \mathrm{C} \mathrm{m}^{-3}$ for warm temperate moist forest, $8.3 \pm 4.6 \mathrm{~kg} \mathrm{C} \mathrm{m}^{-3}$ for warm temperate dry forest, $7.6 \pm 6.8 \mathrm{~kg} \mathrm{C} \mathrm{m}^{-3}$ for warm temperate steppe, $12 \pm$ $8.2 \mathrm{~kg} \mathrm{C} \mathrm{m}^{-3}$ for cool temperate moist forest, $13.3 \pm 9.5 \mathrm{~kg} \mathrm{C} \mathrm{m}^{-3}$ for cool temperate steppe, and $15.5 \pm$ 
$30 \mathrm{~kg} \mathrm{C} \mathrm{m}^{-3}$ for boreal moist forest. The estimates of SOC values under the optimal conditions by the DECP and modified Miami models are well within one standard deviation of the global SOC dataset by Post et al. [48]. Our national range of estimates for SOC storage of $1.3 \mathrm{Pg} \mathrm{C}$ to $36.7 \mathrm{Pg} \mathrm{C}$ by the DECP model and $40.9 \mathrm{Pg} \mathrm{C}$ by the modified Miami model accounts for $0.1 \%, 2.8 \%$, and $3.2 \%$ of the global SOC value (1272.4 Pg C) according to Post et al. [48], respectively.

According to DECP, mean SOC carbon density appeared to decrease for forest and W/S ecosystems and increase for steppe ecosystems in transition from cool temperate to Mediterranean zones. This pattern for forest and W/S reveals that SOC storage decreases in response to an increase in BT and PER (the ratio of PET $_{\mathrm{HLZ}}$ to PPT), and a decrease in elevation and GSP. When PER $(1.1 \pm 0.35)$ approached unity in the cool temperate zone, SOC pool under the cool temperate forest peaked at 12.4 $+3.3 \mathrm{~kg} \mathrm{C} \mathrm{m}^{-3}$ which shows a close agreement with mean SOC pool value of $10 \mathrm{~kg} \mathrm{C} \mathrm{m}^{-3}$ at PER of 1 derived from the global soil dataset [48]. The reverse pattern for steppe ecosystems appears to be due to the increase in TNPP values estimated in transition from cool temperate to Mediterranean zones. On the other hand, the modified Miami model estimated increases in TNPP and SOC for forest, W/S and steppe ecosystems in transition from cool temperate to Mediterranean zones and failed to capture detailed patterns among biogeoclimate variables, SOC storage and TNPP revealed by the DECP algorithm.

Values of vegetation-specific parameters used in the DECP model approximately correspond to those of the biogeochemical models TEM [23], CASA [51] and SILVAN [52]. As with all regression models, MLR models should be used cautiously to estimate response variables at large spatial scales beyond the region from which they are derived. The proposed DECP model does not account for certain areas of a grid cell that may be unsuitable for establishment of natural vegetation (including rivers, lakes, roads, and rock and stony outcrops), and for changes caused by human disturbances (deforestation, urban sprawl, and land-use changes). The model must be further validated by other means available such as satellite images before its use in predicting spatio-temporal responses of biogeoclimate zones, PFTs, TNPP, and SOC to the projected scenarios of global climate change [56]. According to available field and remotely sensed data, the DECP model based on the 37-year mean climatic data was able to generate realistic distributions of potential natural land cover and estimates of TNPP and steady state SOC in Turkey under the limiting and non-limiting conditions in mutually exclusive and inclusive ways of PFTs. The difference between the steady state estimates of net C stocks for potential natural ecosystems under the non-limiting and limiting conditions may reveal the magnitude of historic national $\mathrm{C}$ loss as well as the national potential for $\mathrm{C}$ sequestration if $50 \%$ recovery of $\mathrm{C}$ loss is assumed over the next 50-100 years as a reasonable upper limit in constant climate.

This research provides the first extensive quantification of potential conditions for NPP and SOC in Turkey. Coupling this information with current land-use/land-cover and related NPP would lead to important implications about $\mathrm{C}$ loss due to human-induced disturbances across Turkey since most of the $\mathrm{C}$ loss is most likely to result from alteration of land-use/land-cover, and land management practices. Our model potentially estimated $c a .45 \%$ of the land area of Turkey to be productive forest ecosystems, while only ca. $25 \%$ of the country is currently forested, with more than half being unproductive. This reveals the significant potential for Turkey's forests to sequester $\mathrm{C}$ as well as the importance of sustainable land management practices to achieve $\mathrm{C}$-sequestration potential given rapid 
rates of population growth and conversions of forests and grasslands into urban-industrial and cropland areas.

\section{Acknowledgements}

We gratefully acknowledge the research project grant (KARIYER-TOVAG-104O550) from the Scientific and Technological Research Council (TUBITAK) of Turkey and the Research Project Administration Units of Abant Izzet Baysal University, Cukurova University, and Akdeniz University.

\section{References}

1. Behrenfeld, M.J.; Randerson, J.T.; McClain, C.R.; Feldman, G.C.; Los, S.O.; Tucker, C.J.; Falkowski, P.G.; Field, C.B.; Frouin, R.; Esaias, W.E.; Kolber, D.D.; Pollack, N.H. Biospheric primary production during an ENSO transition. Science 2001, 291, 2594-2597.

2. Hicke, J.A.; Asner, G.P.; Randerson, J.T.; Tucker, C.J.; Los, S.; Birdsey, R.; Jenkins, J.C.; Field, C. Trends in North American net primary productivity derived from satellite observations, 19821998. Global Biogeochemical Cycles 2002, 16, 1018 (doi:10.1029/2001GB001550).

3. Nemani, R.R.; Keeling, C.D.; Hashimoto, H.; Jolly, W.M.; Piper, S.C.; Tucker, C.J.;Myneni, R.B.; Running, S.W. Climate-driven increases in global terrestrial net primary production from 1982 to 1999. Science 2003, 300, 1560-1563.

4. Potter, C.; Klooster, S.; Myneni, R.; Genovese, V.; Tan, P.; Kumar, V. Continental scale comparisons of terrestrial carbon sinks estimated from satellite data and ecosystem modeling 1982-98. Global Planetary Change 2003, 39, 201-213.

5. Hashimoto, H.; Nemani, R.R.; White, M.A.; Jolly, W.M.; Piper, S.C.; Keeling, C.D.; Myneni, R.B.; Running, S.W. El Niño-Southern Oscillation-induced variability in terrestrial carbon cycling. Journal of Geophysical Research 2004, 109, D23110 (doi:10.1029/2004JD004959).

6. Field, C.B.; Behrenfeld, M.J.; Randerson, J.T.; Falkowski, P.G. Primary production of the biosphere: integrating terrestrial and oceanic components. Science 1998, 281, 237-240.

7. Adams, B.; White, A.; Lenton, T.M. An analysis of some diverse approaches to modelling terrestrial net primary productivity. Ecological Modelling 2004, 177, 353-391.

8. Evrendilek, F.; Wali, M.K. Changing global climate: historical carbon and nitrogen budgets and projected responses of Ohio's cropland ecosystems. Ecosystems 2004, 7, 381-392.

9. Wali, M.K.; Evrendilek, F.; West, T.; Watts, S.; Pant, D.; Gibbs, H.; McClead, B. Assessing terrestrial ecosystem sustainability: usefulness of regional carbon and nitrogen models. Nature \& Resources 1999, 35, 20-33.

10. Pan, Y.; Li, X.; Gong, P.; He, C.; Shi, P.; Pu, R. An integrative classification of vegetation in China based on NOAA AVHRR and vegetation-climate indices of the Holdridge life zone. International Journal of Remote Sensing 2003, 24, 1009-1027.

11. Zheng, D.; Prince, S.; Wright, R. Terrestrial net primary production estimates for $0.5^{\circ}$ grid cells from field observations - a contribution to global biogeochemical modeling. Global Change Biology 2003, 9, 46-64.

12. Wilson, M.F.; Henderson-Sellers, A. A global archive of land cover and soils data for use in general circulation climate models. Journal of Climatology 1985, 5, 119-143. 
13. DeFries, R.S.; Townshend, J.R.G. NDVI-derived land cover classification at a global scale. International Journal of Remote Sensing 1994, 15, 3567-3586.

14. Köppen W. Das geographische system der klimate. In Handbuch der Klimatologie; Koppen, W.; Geiger, R., Eds.; Borntrager: Berlin, 1936; pp 1-40.

15. Holdridge, L.R. Determination of world plant formations from simple climate data. Science 1947, 105, 367-368.

16. Box, E.O. Factors determining distributions of tree species and plant functional types. Vegetation 1995, 121, 101-116.

17. Krajina, V.J. Biogeoclimatic zones and biogeocoenoses of British Columbia. Ecology of Western North America 1965, 1, 1-17.

18. Box, E.O. Predicting physiognomic vegetation types with climate variables. Vegetatio 1981, 45, 127-139.

19. Bailey, R.G. Delineation of ecosystem regions. Environmental Management 1983, 7, 365-373.

20. Ollinger, S.V.; Aber, J.D.; Federer, C.A. Estimating regional forest productivity and water yield using an ecosystem model linked to a GIS. Landscape Ecology 1998, 13, 323-334.

21. Running, S.W.; Coughlan, J.C. A general model of forest ecosystem processes for regional applications, I. hydrologic balance, canopy gas exchange and primary production processes. Ecological Modelling 1988, 42, 125-154.

22. Burke, I.C.; Schimel, D.S.; Yonker, C.M.; Parton, W.J.; Joyce, L.A.; Lauenroth, W.K. Regional modeling of grassland biogeochemistry using GIS. Landscape Ecology 1990, 4, 45-54.

23. Raich, J.W.; Rastetter, E.B.; Melillo, J.M.; Kicklighter, D.W.; Steudler, P.A.; Peterson, B.J.; Grace, A.L.; Moore B. III; Vorosmarty, C.J. Potential net primary productivity in South-Americaapplication of a global-model. Ecological Applications 1991, 1, 399-429.

24. Daly, C.; Neilson, R.P.; Phillips, D.L. A statistical-topographical model for mapping climatological precipitation over mountainous terrain. Journal of Applied Meteorology 1994, 33, 140-158.

25. Aber, J.D.; Ollinger, S.V.; Federer, C.A.; Reich, P.B.; Goulden, M.L.; Kicklighter, D.W.; Melillo, J.M.; Lathrop, J.R.G. Predicting the effects of climate change on water yield and forest production in the northeastern US. Climate Research 1995, 5, 207-222.

26. Kicklighter, D.W.; Bondeau, A.; Schloss, A.L.; Kaduk, J.; McGuire, A.D.; the Participants of the Potsdam NPP Model Intercomparison. Comparing global models of terrestrial net primary productivity (NPP): Global pattern and differentiation by major biomes. Global Change Biology 1999, 5, 16-24.

27. Evrendilek, F.; Wali, M.K. Modelling long-term C dynamics in croplands in the context of climate change: a case study from Ohio. Environmental Modelling \& Software 2001, 16, 361-375.

28. Stanley, D.J.; Wezel, F.-C. Geological evolution of the Mediterranean Basin. Springer-Verlag: New York, 1985.

29. GDRS (General Directorate of Rural Services). Digital soil map. Soil and Water Resources National Information Centre: Ankara, 2006.

30. Oakes, H. The soils of Turkey. Ministry of Agriculture, Soil Conservation and Farm Irrigation Division Ministry of Agriculture Publishers: Ankara, 1958. 
31. Soil Survey Staff. Soil classification: a comprehensive system, 7th Approximation. U.S. Governmental Print Office: Washington, D.C., 1960.

32. TSMS (Turkish State Meteorological Service). Monthly climate data between 1968 and 2004. Turkish State Meteorological Service: Ankara, 2005.

33. Woodward, F.I. Climate and plant distribution. Cambridge University Press: New York, 1987.

34. Loveland, T.R.; Reed, B.C.; Brown, J.F.; Ohlen, D.O.; Zhu, Z.; Yang, L.; Merchant, J.W. Development of a global land cover characteristics database and IGBP DISCover from 1-km AVHRR data. International Journal of Remote Sensing 2000, 6, 1303-1330.

35. Paruelo, J.M.; Lauenroth, W.K. Climatic controls of the distribution of plant functional types in grasslands and shrublands of North America. Ecological Applications 1996, 6, 1212-1224.

36. ESRI Inc. ArcGIS 8.2. ESRI Inc.: Redlands, 2002.

37. Monteith, J.L. Solar radiation and productivity in tropical ecosystems. Journal of Applied Ecology 1972, 9, 747-766.

38. Monteith, J.L. Climate and the efficiency of crop production in Britain. Philosophical Transactions of the Royal Society B-Biological Sciences 1977, 281, 277-294.

39. Kumar, M.; Monteith, J.L. Remote sensing of crop growth. In Plants and the Daylight Spectrum; Smith, H., Ed.; Academic Press: London, 1981, pp. 133-144.

40. Ruimy, A.; Saugier, B.; Dedieu, G. Methodology for the estimation of terrestrial primary production from remotely sensed data. Journal of Geophysical Research 1994, 99, 5263-5283.

41. McCree, K.J. Test of current definitions of photosynthetically active radiation against leaf photosynthesis data. Agricultural Meteorology 1972, 10, 443-453.

42. Friedlingstein, P.; Delire, C.; Muller, J.F.; Gerard, J.C. The climate induced variation of the continental biosphere: a model simulation of the Last Glacial Maximum. Geophysical Research Letters 1992, 19, 897-900.

43. Leith, H. Modeling the primary productivity of the world. In Primary productivity of the Biosphere; Leith, H.; Whittaker, R.H., Eds.; Springer-Verlag: New York, 1975, pp. 237-262.

44. Dai, A.; Fung, I.Y. Can climate variability contribute to the 'missing' $\mathrm{CO}_{2}$ sink? Global Biogeochemical Cycles 1993, 7, 599-609.

45. Jenny, H. Factors of soil formation. McGraw-Hill: New York, 1941.

46. Zinke, P.J.; Stangenberger, A.G.; Post, W.P.; Emanual, W.R.; Olson, J.S. Worldwide organic soil carbon and nitrogen data. ORNL/NDP-018, Oak Ridge National Laboratory, Oak Ridge, Tennessee, 1986.

47. Yang, X.; Wang, M.; Huang, Y.; Wang, Y. A one-compartment model to study soil carbon decomposition rate at equilibrium situation. Ecological Modelling 2002, 151, 63-73.

48. Post, W.M.; Pastor, J.; Zinke, P.J.; Stangenberger, A.G. Global patterns of soil nitrogen storage. Nature 1985, 317, 613-616.

49. Running, S.W.; Ramakrishna, R.N.; Heinsch, F.A.; Zhao, M.; Reeves, M.; Hashimotoa, H. Continuous satellite-derived measure of global terrestrial primary production. BioScience 2004, 54, 547-560.

50. Kucharik, C.J.; Foley, J.A.; Delire, C.; Fisher, V.A.; Coe, M.T.; Lenters, J.D.; Young-Molling, C.; Ramankutty, N.; Norman, J.M.; Gower, S.T. Testing the performance of a dynamic global 
ecosystem model: water balance, carbon balance, and vegetation structure. Global Biogeochemical Cycles 2000, 14, 795-825.

51. Potter, C.S.; Randerson, J.T.; Field, C.B.; Matson, P.A.; Vitousek, P.M.; Mooney, H.A.; Klooster, S.A. Terrestrial ecosystem production: A process model based on global satellite and surface data. Global Biogeochemical Cycles 1993, 7, 811-841.

52. Kaduk, J.; Heimann, M. Assessing the climate sensitivity of the global terrestrial carbon cycle model SILVAN. Physics and Chemistry of the Earth 1996, 21, 529-535.

53. Kaya, Z.; Raynal, D.J. Biodiversity and conservation of Turkish forests. Biological Conservation 2001, 97, 131-141.

54. Yue, T.X.; Fan, Z.M.; Liu, J.Y. Changes of major terrestrial ecosystems in China since 1960. Global Planetary Change 2005, 48, 287-302.

55. Zheng, Y.; Xie, Z.; Jiang, L.; Shimizu, H.; Drake, S. Changes in Holdridge Life Zone diversity in the Xinjiang Uygur Autonomous Region (XUAR) of China over the past 40 years. Journal of Arid Environments 2006, 66, 113-126.

56. Berberoglu, S.; Evrendilek, F.; Ozkan, C.; Donmez, C. Modeling forest productivity using Envisat MERIS data. Sensors 2007, 7 (10), 2115-2127.

(C) 2007 by MDPI (http://www.mdpi.org). Reproduction is permitted for noncommercial purposes. 